\title{
DIREITO À CIDADE E DIREITOS NA CIDADE: INTEGRANDO AS PERSPECTIVAS SOCIAL, POLÍTICA E JURÍDICA
}

\author{
RIGHT TO THE CITY AND RIGHTS IN THE CITY: INTEGRATING SOCIAL, POLITICAL \\ AND LEGAL PERSPECTIVES
}

\author{
Virgínia Totti Guimarães ${ }^{1}$
}

\section{Resumo}

O artigo trata do direito à cidade, a partir das discussões estabelecidas nos campos jurídico, social e político, metodologicamente baseado em pesquisa e análise crítica da bibliografia. Analisam-se as previsões legais sobre direito à cidade, considerando-o como um direito fundamental, de natureza difusa, composto por outros direitos sociais e difusos, vinculado à dignidade da pessoa humana e regido pela solidariedade. Entende-se que o direito à cidade e os direitos sociais que o compõem não possuem natureza meramente programática, exigindose que o Estado adote políticas para sua proteção progressiva. O direito à cidade, contudo, não é apenas a soma destes direitos e a inter-relação entre eles; ele se relaciona ao poder de influência e criatividade que as pessoas têm de determinar aspectos fundamentais sobre a cidade em que vivem. O conteúdo do direito à cidade deve ser moldado pela perspectiva política, integrando-o ao poder de decidir e viver o espaço urbano a partir das demandas dos cidadãos. A análise, em conjunto, das noções de direito à cidade de Lefebvre e do ordenamento jurídico intensifica o potencial de politização, afastando-o de sua utilização como um conceito vazio e legitimador de uma cidade cada vez mais excludente.

Palavras-chave: Direito à cidade; função social da propriedade urbana; gestão democrática da cidade; cidade sustentável.

\begin{abstract}
This paper addresses the right to the city from discussions in the legal, social and political fields, methodologically based on research and critical analysis of the field's bibliography. The legal provisions right to the city are analysed, considering it as a fundamental right, of diffuse nature, composed of other social and diffuse rights, bound to human dignity and governed by solidarity. It is understood that the right to the city and social rights that are part of it do not have nature merely programmatic, requiring that the State adopts policies for its progressive protection. However, the right to the city is not only the sum of these rights and the interrelation between them; it is related to the power of influence and creativity that people have to determine essential aspects on city in where they live. The content of the right to the city should be framed by political perspective, integrating it to the power to decide and live the urban space from demands of the citizens. The analysis, together with the notions of right to the city of Lefebvre and the legal system, intensifies the potential of politicization, pushing it away of its use as an empty and legitimating concept of a city increasingly excluding.
\end{abstract}

Keywords: Right to the city; social function of the urban propriety; democratic management of the city; sustainable city.

\footnotetext{
${ }^{1}$ Doutora em Direito pela Pontifícia Universidade Católica do Rio de Janeiro (PUC-Rio). Professora de Direito Ambiental e de Direito Urbanístico da PUC-Rio. Coordenadora Acadêmica do Curso de PósGraduação lato sensu em Direito Ambiental também da PUC-Rio. E-mail: virginia@puc-rio.br
} 


\section{INTRODUÇÃO}

No Brasil, desde os anos 1960, presencia-se a formação de um pensamento crítico que defende a função social da propriedade, gestão democrática da cidade, descentralização e municipalização da política urbana, relacionando estas demandas à garantia do direito à cidade. Originalmente desenvolvido na obra de Lefebvre, o direito à cidade, que logo é incorporado nas demandas de movimentos sociais por reforma urbana, parece ter sido transformado em uma bandeira. Mas não há consensos em relação ao direito à cidade. Ao contrário, é um conceito em disputa, permeado de constante conflito, tal como o próprio espaço urbano. ${ }^{2}$

A análise, em conjunto, das noções de direito à cidade de Lefebvre e do ordenamento jurídico pode demostrar limitações existentes em sua previsão e aplicação no direito brasileiro, mas, ao mesmo tempo, intensificar o potencial de politização, afastando-o de sua utilização como um conceito vazio e legitimador de uma cidade cada vez mais excludente, do ponto de vista territorial e social.

A busca da isonomia e justiça social, nas cidades brasileiras, parece nunca ter estado tão distante. A segregação social, com suas marcas impressas na ocupação territorial, é tão evidente na sociedade brasileira que se coloca quase como natural e, portanto, impossível de ser questionada. Neste cenário, com o atual processo de mercantilização das cidades, com graves consequências para a vida urbana, e, por outro lado, reforçando o lugar da política no espaço urbano, parece imperioso analisar: afinal, é possível definir o direito à cidade? O que se propõe, assim, é uma análise capaz de conjugar diversos elementos do direito à cidade - que inclua aspectos trazidos por Lefebvre -, buscando-se o alargamento dos direitos e garantias que o integram, voltando-se ao questionamento das bases e pilares capitalistas. Além disso, procura-se a noção mais ampla do direito no ordenamento jurídico brasileiro, com destaque para elementos que se consideram fundantes: a função social da propriedade pública e privada, a gestão democrática das cidades e a sustentabilidade dos espaços urbanos.

\footnotetext{
${ }^{2}$ Harvey afirma que direito à cidade é "um significante vazio. Tudo depende de quem the vai conferir significado [...] A própria definição de 'direito' é objeto de uma luta, e essa luta deve ser concomitante com a luta por materializá-lo" e isso não o torna irrelevante ou politicamente sem potência (HARVEY, 2014 , p. 20 e 244).
} 


\section{PERSPECTIVA SOCIAL E POLÍTICA DO DIREITO À CIDADE, A PARTIR DA OBRA DE HENRI Lefebvre}

O direito à cidade não possui apenas um conteúdo jurídico e por isso não está, de modo algum, restrito aos estudos do Direito. Ao contrário, exigências a ele relacionadas são recorrentes nos movimentos sociais e organizações que trabalham com temas urbanos. Henri Lefebvre foi quem primeiro formulou o conceito de direito à cidade e ainda hoje influencia este uso recorrente, destacando, em sua obra, Direito à Cidade (1968) e Revolução Urbana (1970). Neste item, serão apresentados seus principais conceitos e o diálogo como outros autores, objetivando, a seguir, propor uma integração de sua perspectiva social e política com a jurídica.

Lefebvre considera o surgimento de uma sociedade urbana, trabalhando questões filosóficas, políticas e metodológicas, para entender o fenômeno urbano. ${ }^{3}$ Para ele, revolução urbana constitui-se pela passagem "ao período no qual a problemática urbana prevalecerá decisivamente, em que a busca das soluções e das modalidades próprias à sociedade urbana passará ao primeiro plano" (LEFEBVRE, 1999, p. 19).

O autor entende que cidade é um nível específico da realidade social, que não deve ser analisada pelo pressuposto da continuidade histórica ilusória, ${ }^{4}$ mas que se transforma em "razão de 'processos globais' relativamente contínuos" e "em função de modificações profundas no modo de produção, nas relações 'cidade-campo', nas relações de classe e de propriedade" (LEFEBVRE, 2001, p.58).

A cidade de Lefebvre está ligada ao espaço da política, na qual não há uniformidade ou consenso, mas contradições, diferenças e encontros; e a prática social irá determinar a integração de seus elementos, preparando novas formas da vida urbana. O espaço urbano "é

\footnotetext{
${ }^{3}$ Metodologicamente, o autor reconhece a existência de níveis e dimensões que devem ser introduzidos na análise. A proposta é que se parta de um nível mais próximo, por ele denominado como nível $\mathrm{P}$, que corresponderia ao habitar, para se entender o nível G ou global (poder do Estado, política, representação, ou seja, as relações mais gerais, abstratas) e o nível M (misto, intermediário, "especificamente urbano") (LEFEBVRE, 1999, p. 77-79).

Para Lefebvre, a cidade situa-se entre a ordem próxima ("relações entre indivíduos em grupos mais ou menos amplos, mais ou menos organizados e estruturados, relações destes grupos entre eles") e a ordem distante ("a ordem da sociedade, regida por grandes e poderosas instituições", esta é abstrata, formal, suprassensível e transcendente na aparência, concebida dentro das ideologias - religiosas e políticas). "A cidade é uma mediação entre as mediações. Contendo a ordem próxima, ela a mantém; sustenta relações de produção e de propriedade; é o local de sua reprodução. Contida na ordem distante, ela se sustenta; encarna-a; projeta-a sobre um terreno (o lugar) e sobre um plano, o plano da vida imediata; a cidade inscreve essa ordem, prescreve-a, escreve-a, texto num contexto mais amplo e inapreensível como tal a não ser para a mediação" (LEFEBVRE, 2001, p. 52).

${ }^{4}$ Para ele, a regra metodológica é "evitar a confusão numa continuidade ilusória, bem como as separações ou descontinuidades absolutas" (LEFEBVRE, 2001, p. 58).
} 
contradição concreta", sendo "um espaço político, lugar e objeto das estratégias" (Lefebvre, 1999, p. 46 e 50). O direito à cidade pressupõe a existência de um espaço para que a vida política ocorra e se desenvolva, dando origem a projetos utópicos de cidade. Seu conteúdo, assim, relaciona-se ao "direito à vida urbana, transformada, renovada", a partir de apelos, exigências dos habitantes (LEFEBVRE, 2001, p. 117-118, grifos do autor).

Lefebvre afirma que os movimentos urbanos e de luta de classes reforçam o sentimento de pertencer à cidade, mas que a vida em comunidade não impede esta luta. Não há apego à cidade, neste sentido. Os confrontos políticos ocorrem na cidade (LEFEBVRE, 2001, p. 13). A cidade é vista como uma arena na qual se expressam conflitos e contradições (BRENNER et al, 2012, p.1) ou "como um espaço importante de ação e revolta política" (HARVEY, 2014, p. 213). Ao descrever o modo pelo qual as obras de Haussmann possibilitaram a expulsão do proletariado do centro urbano e da própria cidade, permitindo que a burguesia francesa promovesse a ocupação ao seu modo e impedindo a ascensão de uma democracia urbana, Lefebvre afirma "a vida urbana pressupõe encontros, confrontos das diferenças, conhecimentos e reconhecimentos recíprocos (inclusive no confronto ideológico e político) dos modos de viver, dos 'padrões' que coexistem na cidade" (LEFEBVRE, 2001, p.22). ${ }^{5}$

Em outras palavras, a cidade, como local da contradição, não deveria comportar projetos uniformizadores, que promovem a despolitização dos conflitos urbanos e fazem desaparecer a capacidade criadora da cidade (LEFEBVRE, 2001, p. 13). Nas palavras de Santos Junior,

[...] podemos dizer que os conflitos urbanos que acontecem cotidianamente em torno da mercantilização ou da desmercantilização da moradia, da terra e dos equipamentos coletivos estão relacionados ao direito à cidade. Mas o desafio é avançar na construção de novos projetos de cidades, novos projetos de sociedade. Nesse sentido, o direito à cidade deve converter-se não apenas em um programa anticapitalista, mas em uma nova utopia capaz de se traduzir em uma agenda unificadora dos movimentos sociais em torno de uma cidade justa e democrática para todos e para todas (SANTOS JUNIOR, 2011, p. 74).

\footnotetext{
${ }^{5}$ Harvey enfatiza que a reprodução do capital passa por processos de urbanização, de muitos modos, o que pressupõe a dominação do processo urbano pela classe capitalista (HARVEY, 2014, p. 133). No entanto, nesta relação entre desenvolvimento capitalista e urbanização, o autor afirma que, além de dar conta dos problemas relacionados aos excedentes de capital, há a criação de um novo estilo de vida urbana e de um novo tipo de persona urbana (HARVEY, 2014, p.35). E, neste sentido, "a urbanização desempenhou um papel crucial na absorção de excedentes de capital, e que o tem feito em escala geográfica cada vez maior, mas ao preço de processos florescentes de destruição criativa que implicam a desapropriação das massas urbanas de todo e qualquer direito à cidade" (HARVEY, 2014, p.59).
} 
O termo 'político' foi usado, pelo autor, para se referir a classes sociais, frações ou agrupamentos delas, que devem "indicar suas necessidades sociais, inflectir as instituições existentes, abrir os horizontes e reivindicar um futuro que será obra sua" (LEFEBVRE, 2001, p. 122-123). Neste sentido, a práxis assume posição central, como forma de recomposição da cidade:

A cidade não é apenas uma linguagem, mas uma prática [...] Apenas uma praxis, em condições a serem determinadas, pode se encarregar da possibilidade e da exigência de uma síntese, da orientação na direção desse objetivo: a reunião daquilo que se acha disperso, dissociado, separado, e isso sob a forma da simultaneidade e dos encontros (LEFEBVRE, 2001, p. 101-102). ${ }^{6}$

O esforço deve ser em direção a uma nova vida social urbana, com toda sua capacidade de alteração da ordem urbana, e a um "novo homem da sociedade urbana", propõe Lefebvre (LEFEBVRE, 2001, p. 108).?

Questão importante para Lefebvre é a posição do utópico na cidade. Para ele, (u)tópico, como o não lugar, não é imaginário, está presente desde sempre na cidade (LEFEBVRE, 1999, p. 46). O autor afirma que, com ações políticas escalonadas no tempo da ação política, o impossível hoje se torna possível amanhã (LEFEBVRE, 2001), colocando-se ênfase na possibilidade de se constituírem novos desejos e de que estes possam ser realizados. Importa que sejam descobertas as novas necessidades que emergem desta realidade urbana: "o homem da sociedade urbana já é um homem rico em necessidades" (LEFEBVRE, 2001, p. 124). ${ }^{8}$ Ou, nas palavras de Harvey,

somente quando se entender que os que constroem e mantêm a vida urbana têm uma exigência fundamental sobre o que eles produziram, e

\footnotetext{
${ }^{6}$ A prática social é, de um lado, integrativa, que "procura integrar seus elementos num todo coerente", e segregadora. Transforma-se a integração em uma obsessão (na verdade, "uma aspiração sem objetivo", nas palavras do autor). A participação igualmente é uma obsessão: "na prática, a ideologia da participação permite obter pelo menor preço a aquiescência das pessoas interessadas e que estão em questão" (LEFEBVRE, 2001, p. 103-104).

${ }^{7}$ Com a tarefa inicial de desconstituir estratégias e ideologias dos grupos dominantes, "apenas grupos, classes ou frações de classes sociais capazes de iniciativas revolucionárias podem se encarregar das [...] soluções para os problemas urbanos" (Lefebvre, 2001, p. 113). E os projetos não podem ser realizados sem a classe operária, sendo a "única capaz de pôr fim a uma segregação dirigida essencialmente contra ela": a "integração sem ela não tem sentido, e a desintegração continuará, sob a máscara e a nostalgia da integração" (LEFEBVRE, 2001, p.113).

${ }^{8}$ A questão torna-se central no Brasil, especialmente considerando-se a intensificação da mercantilização das cidades, devendo-se promover uma atualização do ideário do direito à cidade, que seja "capaz de propor mecanismos de um novo tipo de coesão social baseado na negação da segregação social, na promoção da função social da cidade e da propriedade, na gestão democrática, e na difusão de uma nova cultura social, territorial e ambiental que promova padrões de sociabilidade com base na solidariedade, na construção de identidades e na representação de interesses coletivos" (RIBEIRO; Santos Junior, 2011, p. 15).
} 
que uma delas é o direito inalienável de criar uma cidade mais em conformidade com seus verdadeiros desejos, chegaremos a uma política do urbano que venha a fazer sentido (HARVEY, 2014, p. 21).

Neste sentido, o direito à cidade está ligado aos projetos utópicos construídos a partir dos desejos e necessidades nesta sociedade urbana, promovendo a "emancipação humana. Ele é o direito de reconstruir a cidade da perspectiva da justiça social e felicidade" (SANTOS JUNIOR, 2014, p. 152)..$^{9}$ Direito à cidade deve ser entendido, assim, como um slogan político, "um grito, uma demanda, uma reivindicação" (MARCUSE, 2010, p. 89); um projeto coletivo de uma nova cidade, e, de outro lado; deve ser entendido como uma exigência, uma demanda pela provisão de reprodução social na cidade (MARCUSE apud SANTOS JUNIOR, 2014, p. 152).

Na mesma linha, Harvey afirma que "o direito à cidade não deve ser entendido como um direito ao que já existe, mas como um direito de reconstruir e recriar a cidade como um corpo político socialista com uma imagem totalmente distinta: que erradique a pobreza e a desigualdade social e cure as feridas da desastrosa degradação ambiental" (HARVEY, 2014, p. 247). Seria um direito que envolve a possibilidade de transformar a cidade em algo totalmente diverso. ${ }^{10}$

O direito à cidade, assim, não é individual, já que relacionado à reinvenção da cidade que "depende inevitavelmente do exercício de um poder coletivo sobre o processo de urbanização", sendo que aquele está menos relacionado ao acesso a recursos incorporados na e pela cidade, mas sim ao "direito de mudar e reinventar a cidade mais de acordo com nossos mais profundos desejos". Neste sentido, o autor afirma que a própria liberdade "de fazer e refazer a nós mesmos e a nossas cidades" é um dos nossos direitos humanos mais precisos, ainda que seja um dos mais menosprezados (HARVEY, 2014, p. 28).

Marcuse, contudo, diferencia os direitos nas cidades de direito à cidade. O direito à cidade, como visto, tem um caráter de radicalidade, a partir da elaboração de Lefebvre, "com o

\footnotetext{
9 "Para Lefebvre, consequentemente, o direito à cidade significa o direito a viver numa sociedade onde todas as pessoas têm a mesma liberdade para satisfazer seus próprios desejos e onde todos recebem apoio para fazê-lo" (MARCUSE, 2010, p. 90).

10 Harvey afirma que a importância do resgate de direito à cidade está menos ligada à importância do legado de Lefebvre, mas sim ao que emerge dos movimentos sociais urbanos, inclusive mencionando expressamente o caso brasileiro (HARVEY, 2014, p. 13-14). E que a relevância de estudar Lefebvre está relacionada à necessidade de se entender como os acadêmicos e intelectuais respondem a esta exigência que emerge dos movimentos sociais: "seu método dialético de investigação crítica imanente pode oferecer um modelo inspirador sobre como poderíamos responder a essa queixa e a essa exigência", nos dias atuais (HARVEY, 2014, p. 16). O autor trata de concepções e ideias de Lefebvre desde a publicação de "A justiça social e a cidade", de 1973, o que foi retomado explicitamente com a publicação de "Cidades rebeldes", de 2012, no qual estabelece um diálogo direto com o autor (SANTOS JUNIOR, 2014, p. 147).
} 
objetivo de ampliar o âmbito das demandas de mudança social para englobar a visão de uma sociedade diferente" (MARCUSE, 2010, p. 89). Os direitos nas cidades, com formulação no plural, teriam o sentido de enumerar os diversos direitos que seriam exigíveis e exercidos no âmbito da cidade, como moradia, meio ambiente equilibrado, mobilidade. Segundo o autor, embora concordem com a demanda do direito à cidade, são direitos parciais, com demandas específicas a determinados grupos: "Um aspecto pode ser um passo importante para o outro, mas são diferentes e possuem formulações diversas" (MARCURSE, 2010, p. 90). ${ }^{11}$ E conclui: "É necessário demandar, proteger e lutar pelos diversos direitos à cidade. Serão plenamente concretizados quando se atinja o direito à cidade" (MARCUSE, 2010, p. 100).

Em diferente sentido, para Santos Junior cada uma destas lutas pode ser considerada parte do direito à cidade. Enquanto exigência ou demanda, o direito à cidade liga-se a uma agenda concreta de lutas contra desapossamentos, como as relacionadas à moradia, mobilidade, saúde e participação democrática, traduzindo-se em diversas agendas do movimento por reforma urbana na América Latina (SANTOS JUNIOR, 2014, p. 152). Deve-se, contudo, unir estas duas perspectivas do direito à cidade, dado que envolve, necessariamente, o fortalecimento e surgimento de fortes movimentos sociais urbanos.

Na mesma linha integradora do direito à cidade, que não o diferencia dos direitos na cidade, perspectiva com a qual se adere neste artigo, Fernandes afirma que a concepção política e social de Lefebvre deve servir para abrir uma linha de argumentação sobre a ordem legal, que apresente uma crítica a partir de dentro desta ordem. Neste sentido, na América Latina, desde meados de 1970, presencia-se uma mobilização social, tentar unir as concepções políticas e sociais do direito à cidade (FERNANDES, 2007, p. 208), ainda que o processo seja cheio de contradições e desafios (p. 218).

O direito à cidade relaciona-se, assim, aos anseios de quem mora, trabalha, sobrevive, produz no espaço urbano: ele deve ser definido por processos de participação - que não sejam meramente formais -, pelas experiências, inclusive as práticas espontâneas vivenciadas na cidade. Ele está marcado pelo poder de alteração e decidir, de modo amplo, os destinos e projetos para o espaço urbano. Trata-se, portanto, de conteúdo que terá diretos reflexos

\footnotetext{
${ }^{11}$ Marcuse apresenta três consequências políticas diversas desta distinção entre direitos na cidade e direitos à cidade: (i) a demanda de um direito único, que inclua todos os direitos que separadamente vem sendo exigido por diferentes forças, grupos e organizações, tem o condão de unir as pautas daqueles que, no início, tem prioridades práticas diferentes; (ii) a visão unitária do direito confere uma perspectiva analítica que permite dar uma visão do todo, mesmo diante de fenômenos que atingem de modo diferente, diversos grupos; (iii) reforça a esperança em um futuro diferente e mais justo, que não se limita a um problema específico e particular (MARCUSE, 2010, p. 90-91).
} 
jurídicos, podendo-se destacar o direito à gestão democrática da cidade. Somam-se, a esses aspectos, outros contornos definidos pelo direito brasileiro, que serão analisados no item seguinte.

\section{O DIREITO À CIDADE NO ORDENAMENTO JURÍDICO BRASILEIRO}

Ao longo das últimas décadas, o Direito tenta - de certo modo, com dificuldade acompanhar o complexo fenômeno urbano por meio de necessárias e profundas modificações, ${ }^{12}$ tanto em relação ao conteúdo das normas, quanto sobre interpretação e aplicação destas. Neste contexto, o objeto do presente item é refletir sobre as formulações do direito à cidade no âmbito jurídico brasileiro, com objetivo de proceder à sua integração com as formulações nas dimensões política e social, apresentadas anteriormente.

A Constituição Federal de 1988 traz, pela primeira vez história constitucional do Brasil, um capítulo sobre política urbana, atendendo a demandas de movimentos por reforma urbana. Em grande parte, este capítulo foi feito com base Emenda Popular de Reforma Urbana, elaborada e assinada por mais de 100.000 organizações sociais e indivíduos envolvidos no Movimento Nacional de Reforma Urbana, ${ }^{13}$ atualmente Fórum Nacional de Reforma Urbana, ${ }^{14}$ que tinha como seus princípios gerais:

\footnotetext{
${ }^{12}$ Entende-se que há uma "lógica subjacente intrínseca à produção e à reprodução capitalista do espaço, lógica que está na própria origem do processo de acumulação do capital, caracterizado pelo desenvolvimento desigual e combinado das forças produtivas e pela contradição fundamental da qual deriva a sociabilidade própria do capitalismo" (COUTINHO, 2007, p. 19). No entanto, igualmente considera-se que o Direito pode e deve estabelecer instrumentos voltados à alteração dos padrões de dominação social, capazes de gerar transformações, como as desejadas no padrão vigente de segregação espacial. Ou nas palavras de FERNANDES: "Não há como promover mudanças significativas e estruturais desse padrão de exclusão social, segregação territorial, degradação ambiental e ilegalidade urbana que caracteriza o processo de urbanização no Brasil, se não for também mediante uma reforma do Direito, com o envolvimento sistemático dos operadores do Direito nas parcerias acadêmicas e politicoinstitucionais que tem se formado" (FERNANDES, 2006, p. 05).

${ }^{13}$ No processo histórico de formação do movimento por reforma urbana no Brasil, Saule Junior e Uzzo destacam a importância da Igreja Católica que elaborou o documento "Ação Pastoral e o Solo Urbano", resultado da Conferência Nacional dos Bispos do Brasil, realizada em 1982, no qual expressamente defendia-se o condicionamento do direito de propriedade à sua função social (SAULE JUNIOR, UZZO, 2010, p. 161). O documento da Igreja Católica encontra-se disponível em: <http://www.cnbb.org.br/component/docman/doc_download/85-23-solo-urbano-e-acao-pastoral>. Acesso em: 18 jan.2017.

${ }^{14}$ Ainda hoje, o Fórum Nacional por Reforma Urbana segue atuante e busca pautar as ações relacionadas ao tema. Como exemplo, menciona-se a carta encaminhada à Presidenta da República com destaque para os desafios das políticas urbanas e com o pleito de indicação de um ministro das cidades comprometido com a garantia do direito à cidade. Disponível em: <http://reformaurbana.tumblr.com/post/102194484153/carta-\%C3\%A0-presidente-da-rep\%C3\%BAblica-federativa-do>. Acesso em: 18 jan.2017.
} 
i. autonomia do governo municipal;

ii. gestão democrática das cidades;

iii. direito social de moradia;

iv. direito à regularização de assentamentos informais consolidados;

v. função social da propriedade urbana;

vi. combate à especulação imobiliária nas áreas urbanas (FERNANDES, 2010, p. 127).

Ainda que propostas como a criação de instrumentos urbanísticos e jurídicos para combater a especulação, possibilitar a expropriação de terra urbana ociosa, regularizar favelas e ocupações, tenham sofrido dura oposição na Assembleia Constituinte, (BONDUKI, 2009, p. 177), a Constituição consagra outros princípios e instrumentos necessários à gestão das cidades, como a exigência de uma política de desenvolvimento urbano a ser executada pelos municípios, com objetivo de ordenar o pleno desenvolvimento das funções sociais da cidade e garantir o bem- estar de seus habitantes (artigo 182). Neste sentido, "apesar da articulação conservadora, que limitou inúmeros avanços, a Constituição de 1988 é um marco legal da construção de uma gestão democrática nas políticas públicas no Brasil” (BONDUKI, 2009, p. 177).

A Constituição de 1988 prevê, ainda, um destacado posicionamento dos municípios na atuação para os assuntos urbanos, também demanda dos movimentos sociais, por meio de suas competências para assuntos de interesse local (art. 30, I), organizar e prestar, diretamente ou sob regime de concessão ou permissão, os serviços públicos de interesse local, incluído o de transporte coletivo, que tem caráter essencial (art. 30, V), promover, no que couber, adequado ordenamento territorial, mediante planejamento e controle do uso, do parcelamento e da ocupação do solo urbano (art. 30, VIII). Lembra-se, contudo, que a União detém competência para instituir diretrizes para o desenvolvimento urbano, inclusive habitação, saneamento básico e transportes urbanos (art. 21, XX).

Os Estados possuem competência que cada vez mais se destaca, dada a realidade de ocupações urbanas contínuas: a de instituir regiões metropolitanas, aglomerações urbanas e microrregiões, constituídas por agrupamentos de municípios limítrofes, para integrar a organização, o planejamento e a execução de funções públicas de interesse comum (art. 25, § 3o). ${ }^{15} 16$ Há uma intensa dificuldade em compatibilizar o sistema de repartição de competências

\footnotetext{
${ }^{15} \mathrm{Na}$ Constituição de 1967, editada durante do Regime Militar, havia previsão de instituição de regiões metropolitanas pela União, que seriam "constituídas por Municípios que, independentemente de sua vinculação administrativa, integrem a mesma comunidade socioeconômica, visando à realização de serviços de interesse comum" (art. 157, § 10). Lembra-se que, até a Constituição de 1988, os municípios não possuíam autonomia.
} 
constitucionais, que privilegia a posição dos municípios nas questões urbanas, e a realidade das regiões metropolitanas, que demandam políticas que não conhecem limites territoriais e políticos dos entes federativos municipais. ${ }^{17}$

Além disso, há uma série de competências comuns a todos os entes federativos que dizem respeito ao direito à cidade, podendo-se mencionar a promoção de programas de construção de moradias e a melhoria das condições habitacionais e de saneamento básico (art. 23, IX) e a proteção do meio ambiente e da cultura (art. 23, III, IV, V, VI e VII).

Em 2001, após longa espera, o capítulo constitucional da política urbana foi regulamentado pela Lei federal 10.257 - o Estatuto da Cidade - que avança em relação ao texto constitucional e consagra como uma das diretrizes gerais da política urbana a "garantia do direito a cidades sustentáveis, entendido como o direito à terra urbana, à moradia, ao saneamento ambiental, à infraestrutura urbana, ao transporte e aos serviços públicos, ao trabalho e ao lazer, para as presentes e futuras gerações" (artigo 2으, caput e inciso I). ${ }^{18}$ O direito à cidade, assim, passa a integrar expressamente o ordenamento jurídico brasileiro.

Ao interpretar o tratamento jurídico brasileiro, Cavallazzi entende o direito à cidade como

expressão do direito à dignidade da pessoa humana, o núcleo de um sistema composto por um feixe de direitos que inclui o direito à moradia - implícita a regularização fundiária -, à educação, ao trabalho, à saúde, aos serviços públicos - implícito o saneamento -, ao lazer, à segurança, ao transporte público, à preservação do patrimônio cultural, histórico e paisagístico, ao meio ambiente natural e construído equilibrado - implícita a garantia do direito às cidades sustentáveis como direito humano na categoria dos interesses difusos (CAVALLAZZI, 2007, p. 56-57).

Molinaro afirma que o direito à cidade é um dos mais importantes dos direitos humanos, já que relacionado à capacidade de fazer e refazer as cidades, o que se liga ao fazer e

\footnotetext{
${ }^{16} \mathrm{Em} \mathrm{2015,} \mathrm{foi} \mathrm{editado} \mathrm{o} \mathrm{Estatuto} \mathrm{da} \mathrm{Metrópole} \mathrm{que} \mathrm{traz} \mathrm{diretrizes} \mathrm{gerais} \mathrm{para} \mathrm{o} \mathrm{planejamento,} \mathrm{gestão} \mathrm{e}$ execução das funções públicas de interesse comum em regiões metropolitanas e em aglomerações urbanas, além de normas gerais sobre o plano de desenvolvimento urbano integrado e outros instrumentos de governança interfederativa (Lei 13.089/2015).

${ }^{17}$ Com objetivo de exemplificar esta dificuldade, menciona-se que o STF entendeu inconstitucional a Lei do Estado do Rio de Janeiro que instituiu a Região Metropolitana do Rio de Janeiro e a Microrregião dos Lagos, que, em linhas gerais, transferiu ao Estado as funções e os serviços públicos de interesse comum (BRASIL, 2013).

${ }^{18}$ Embora a norma brasileira trate de direito a cidades sustentáveis, entende-se que se refira a conteúdo similar ao de direito à cidade, não cabendo estabelecer diferença entre tais expressões.
} 
refazer das características de seres humanos, mas que, contudo, tem sido o mais negligenciado. Além disso, trata-se de um direito social, "comum a todos, pois todo o processo de transformação e requalificação leva de modo inexorável ao aprendizado do exercício do poder coletivo objetivando melhores condições urbanísticas para a convivência" (MOLINARO, 2009, p. 24). ${ }^{19} 20$

Para Saule Junior, direito à cidade é um direito fundamental, sendo que, no Brasil, se encontra

no mesmo patamar dos demais direitos de defesa dos interesses coletivos e difusos, como por exemplo o do consumidor, do meio ambiente, do patrimônio histórico e cultural, da criança e adolescente, da economia popular. Esta experiência brasileira é inovadora quanto ao reconhecimento jurídico da proteção legal do direito à cidade, na ordem jurídica interna de um país (SAULE JUNIOR, 2005, online).

O direito à cidade - assim como outros novos direitos de natureza coletiva e difusa "reflete a explosão de movimentos sociais não convencionais que traduzem conflitos sociais inéditos, fazendo surgir novos atores sociais e sujeitos coletivos de direitos" (PIOVESAN, 2011, p. 59). Surgem, assim, novos direitos e outros sujeitos de direito, que antes estavam ocultos no cenário jurídico e político (SOUZA FILHO, 2010, p. 475-495).

O direito à cidade é, assim, um direito fundamental, com previsão constitucional, de natureza difusa, composto por outros direitos sociais e difusos, ${ }^{21}$ vinculado à dignidade da pessoa humana e regido pela solidariedade, que teve sua origem em demandas de movimentos sociais, especificamente os relacionados à reforma urbana, e contrapõe-se, muitas vezes, a direitos individuais, de conteúdo patrimonial e contratualista.

19 "O direito humano à cidade é um direito social, ademais de um direito de desfrute individual. Os direitos humanos são direitos de desfrute individual, todavia para sua concretização necessária a luta por eles, o que se faz coletivamente, envolvendo o social, o cultural, o ambiental e o político em processos emancipatórios cujas conquistas os conferem de forma comunitária." (MOLINARO, 2009, p. 24).

20 Trindade, a partir de Thomas H. Marshall e Norberto Bobbio, igualmente entende que o direito à cidade é um direito social, na medida em que constitui uma obrigação positiva do Estado, "cuja finalidade reside na garantia da segurança material e do bem-estar coletivo aos cidadãos diante dos mecanismos excludentes que constituem o fundamento da economia de mercado" (TRINDADE, 2012, p. 155-156).

${ }^{21}$ Cabe notar que, embora o foco desta discussão esteja nos direitos sociais, os direitos humanos, segundo concepção contemporânea, são universais e indivisíveis: "Universalidade, porque clama pela extensão universal dos direitos humanos, sob a crença de que a condição de pessoa é o requisito único para a titularidade de direitos, considerando o ser humano como um ser essencialmente moral, dotado de unicidade existencial e dignidade. Indivisibilidade, porque a garantia dos direitos civis e políticos é condição para a observância dos direitos sociais, econômicos e culturais - e vice-versa. Quando um deles é violado, os demais também o são. Os direitos humanos compõem, assim, uma unidade indivisível, interdependente e inter-relacionada, capaz de conjugar o catálogo de direitos civis e políticos ao catálogo de direitos sociais, econômicos e culturais. Consagra-se, desse modo, a visão integral dos direitos humanos" (PIOVESAN, 2004, p.22). 
Os direitos fundamentais sociais, ${ }^{22}$ tradicionalmente, são interpretados como os que indicam direito a prestações, ou seja, que requerem uma ação positiva, um fazer, por parte do Estado (QUEIROZ, 2006, p. 26), estando relacionados ao emprego de "meios intervencionistas para estabelecer o equilíbrio na repartição dos bens sociais" e instituir "um regime de garantias concretas e objetivas, que tendem a fazer vitoriosa uma concepção democrática de poder, vinculada primacialmente com a função e fruição dos direitos fundamentais" (BONAVIDES, 2008, p. 74). ${ }^{23}$

É certo que os direitos sociais são protegidos por meio de intervenções estatais e “'proteger direitos', nesse âmbito, significa 'realizar direitos'. Por isso, pode-se dizer que o âmbito de proteção de um direito social é composto pelas ações estatais que fomentem a realização desse direito" (SILVA, 2009, p. 77, grifos do autor).

Dentro da discussão sobre a garantia de execução de políticas públicas, abre-se um largo debate sobre as políticas exigíveis, inclusive judicialmente. Denota-se claramente disputa política que envolve a realização de direitos, mesmo que previstos na Constituição Federal.

Sundfeld entende que os direitos previstos no art. 2으, I, Lei 10.257/2001, são direitos subjetivos que não são assegurados individualmente e em concreto, mas como um direito coletivo, que deve ser voltado à fruição individual das vantagens decorrentes da cidade sustentável. E afirma três consequências deste entendimento: possibilita sanção jurídica a inércia do poder público, fornece "parâmetros normativos para controle das orientações seguidas pela política urbana, com isso viabilizando a invalidação das normas e atos a eles contrários", e permite obstar comportamentos privados que contrariem o equilíbrio urbano (SUNDFELD, 2006, p. 55).

\footnotetext{
22 O Pacto Internacional sobre Direitos Econômicos, Sociais e Culturais foi adotado pela XXI Sessão da Assembleia-Geral das Nações Unidas, em 19 de dezembro de 1966, e entrou em vigor no Brasil em 24/04/1992, e promulgado por meio do Decreto 591/1992. Dentre os direitos assegurados pelo Pacto, destacam-se: direito ao trabalho em condições justas e favoráveis, direito de toda pessoa a um nível de vida adequando para si próprio e sua família, inclusive à alimentação, vestimenta e moradia adequadas, assim como a uma melhoria contínua de suas condições de vida, direito de toda pessoa de desfrutar o mais elevado nível possível de saúde física e mental, que inclui a melhoria de todos os aspectos de higiene do trabalho e do meio ambiente.

${ }^{23}$ Temas relacionados aos direitos sociais são amplamente debatidos no direito brasileiro, especialmente em relação à sua realização por políticas públicas e a exigibilidade destas em âmbito judicial. Não é o objetivo desse artigo analisar com profundidade estas interessantes questões relacionadas à exigibilidade do direito à cidade - e dos direitos sociais que o compõem -, mas apresenta-se, mesmo que brevemente, alguns debates relacionados.
} 
Sobre a exigibilidade dos direitos sociais, ${ }^{24}$ Sarmento avalia que se passou de um estágio em que os consideravam como normas programáticas e, portanto, não passíveis de exigibilidade, a outro em que decisões judiciais estabelecendo a prestação de políticas públicas relacionadas a direitos sociais previstos na Constituição Federal são cada vez mais frequentes. Embora considere um notável avanço, o autor coloca em discussão a escassez de recursos para desenvolvimento de todas as políticas públicas necessárias à satisfação de direitos sociais constitucionalmente positivados, bem como a via para alcança-los não ser democrática (SARMENTO, 2008a, p. 553-554). O esforço atual dos autores parece ser a definição de critérios objetivos para exigibilidade dos direitos sociais assegurados constitucionalmente, seja partindo da tese de que igualmente se trata de direitos fundamentais ou por meio da definição do próprio conteúdo de mínimo existencial.

Mesmo diante das discussões apresentadas, contudo, alia-se aos autores que entendem que o direito à cidade e os direitos sociais que o compõem são direitos fundamentais, de natureza não meramente programática, de aplicação imediata, exigindo-se que o Estado adote políticas para sua proteção progressiva. Entende-se que o direito pode ser imediatamente exigido, inclusive determinando alteração de políticas públicas contrárias à garantia de direitos sociais, proteção contra a ofensiva de terceiros ou adoção de medidas que importam em custos que não comprometerão outros direitos. Reconhece-se, contudo, que, em casos extremos, por conta de comprovada limitação de recursos para execução de políticas públicas, estas podem ser restringidas a determinadas situações, adiando a universalidade ou atendimento integral do direito, mas, ainda assim, com o estabelecimento de prazos e condições para a atuação do Estado.

No meio deste debate, destacam-se algumas regras que orientam a aplicação dos direitos sociais, decorrentes das normas constitucionais e documentos internacionais. A primeira é que se deve buscar o atendimento, satisfação ou realização progressivos, ${ }^{25}{ }^{26}$ não

\footnotetext{
${ }^{24}$ A discussão está posta em relação à escassez de recursos para satisfação de todos os direitos fundamentais, sendo mais marcante em relação aos sociais. "A escassez obriga o Estado em muitos casos a confrontar-se com verdadeiras "escolhas trágicas", pois, diante da limitação de recursos, vê-se forçado a eleger prioridades dentre várias demandas igualmente legítimas" (SARMENTO, 2008a, p. 555-556). Além disso, discute-se a reserva do possível, que se trata de uma matéria de defesa que o Estado poderia alegar para demonstrar a impossibilidade de atendimento da prestação requerida, restando larga discussão sobre o tema (SARMENTO, 2008b).

${ }^{25}$ Neste sentido, encontra-se o artigo 20 do Pacto Internacional sobre Direitos Econômicos, Sociais e Culturais ("Cada Estado Parte do presente Pacto compromete-se a adotar medidas, tanto por esforço próprio como pela assistência e cooperação internacionais, principalmente nos planos econômico e técnico, até o máximo de seus recursos disponíveis, que visem a assegurar, progressivamente, por todos
} 
cabendo retrocesso em relação à proteção e garantia do direito à cidade. Neste sentido, devese buscar um atendimento cada vez maior dos direitos sociais, devendo a proteção destes sempre seguir em um sentido: o do pleno atendimento. Por isso, além deste caminhar constante, não se admite que seja adotada medida que importe em redução na proteção destes direitos. ${ }^{27}$

Além disso, a aplicação dos direitos sociais deve ocorrer de forma isonômica, respeitando-se as diferenças, mas sem qualquer tipo de discriminação, o que vai ao encontro dos objetivos fundamentais da República e Pacto Internacional sobre Direitos Econômicos, Sociais e Culturais. ${ }^{28}$ A garantia do bem-estar dos habitantes da cidade relaciona-se à dignidade da pessoa humana, um dos fundamentos da República Federativa do Brasil (art. 1으, III, Constituição Federal), bem como à construção de uma sociedade livre, justa e solidária e à promoção do bem de todos, sem preconceitos de origem, raça, sexo, cor, idade e quaisquer outras formas de discriminação, que são objetivos da mesma (art. 3ํ, I e IV, Constituição Federal). E, neste aspecto, nenhuma política pública relacionada a direitos fundamentais pode afastar-se de tais preceitos.

Neste sentido, outras regras constitucionais não podem ser ignoradas neste processo de concretização progressiva dos direitos fundamentais. No caso do direito à cidade, por exemplo, deve-se, sempre, atender-se à garantia de bem-estar de seus habitantes, acima mencionado, e o pleno desenvolvimento das funções sociais da cidade (art. 182, caput, Constituição Federal).

A cidade deve cumprir uma função social, sendo esta determinada pelo constante movimento e desejos de seus habitantes. Na cidade, como um resultado coletivo, irá se

os meios apropriados, o pleno exercício dos direitos reconhecidos no presente Pacto, incluindo, em particular, a adoção de medidas legislativas").

${ }^{26}$ Molinaro entende que os direitos sociais não são normas programáticas, que incluem obrigações que devem ser imediatamente cumpridas, como "pelo menos, um nível mínimo de usufruto dos elementos essenciais aos direitos humanos, tais como o acesso aos alimentos, cuidados básicos de saúde, a moradia, a educação, o emprego, a segurança e a inclusão dos marginalizados" e que, no Brasil, a progressividade ocorre apenas para desenvolvimento de novas necessidades (MOLINARO, 2009, p.28).

27 "[...] há um autêntico dever do Estado (um ente que se presenta e representa uma pluralidade de seres humanos) de proteção, e da mais ampla realização dos direitos atribuídos aos humanos, positivados ou objetiváveis na ordem internacional, ou na ordem local das constituições, proteção e concretização esta que vai sendo construída gradualmente, sempre e na medida da premência dos bens necessários a satisfação das necessidades" (MOLINARO, 2009, p. 30).

${ }^{28}$ O mesmo artigo 20 do Pacto Internacional sobre Direitos Econômicos, Sociais e Culturais determina: "Os Estados Partes do presente Pacto comprometem-se a garantir que os direitos nele enunciados e exercerão em discriminação alguma por motivo de raça, cor, sexo, língua, religião, opinião política ou de outra natureza, origem nacional ou social, situação econômica, nascimento ou qualquer outra situação." Além disso, o artigo 3o do Pacto impede a discriminação de gênero na garantia dos direitos em questão. 
determinar as funções sociais que dela se esperam. Neste sentido, LIRA afirma que as cidades se constituem como "realizações coletivas, talvez o fato coletivo, por excelência, da sociedade dos homens; são realizações que, por conseguinte, interessam à coletividade inteira, condicionam a vida comunitária e pessoal de todos os membros da coletividade" (LIRA, 1997, p. 159). Estas orientações estão de acordo com o sentido de direito à cidade de Lefebvre e, com elas, afirma-se, em sentido oposto, que não se definem as funções sociais da cidade por meio da vontade dos governantes e muito menos partindo dos interesses de apenas um ou outro grupo.

De modo complementar, mas com outro enfoque, Sundfeld entende que as funções sociais da cidade ("fornecer às pessoas moradia, trabalho, saúde, educação, cultura, lazer, transporte etc") têm que ser cumpridas pelas partes que compõem a cidade, que são as propriedades públicas e particulares, o que será traduzido com a função social da propriedade (SUNDFELD, 2006, p. 54). ${ }^{29}$ Cavallazzi relaciona função social da cidade, tutela da paisagem e o conceito de espaço público: "a realização da função social da cidade está na razão direta da concreção do conceito de espaço público como elemento mediador na desejada relação de equilíbrio entre o meio ambiente natural e o construído" (CAVALLAZZI, 2007, p. 59). A função social da cidade, expressa por meio de atribuições, serviços, ações que devem ser fornecidas para a sociedade, encontra concretude por meio da função social das propriedades urbanas, públicas ou privadas, que será definida no plano diretor, e dos espaços públicos.

A garantia do direito à cidade deve ser entendida, ainda, em consonância com as diretrizes da política urbana, podendo-se destacar a gestão democrática da cidade (art. 2o, II, Lei 10.257/2001), planejamento das cidades como forma de evitar e corrigir as distorções do crescimento urbano e seus efeitos negativos sobre o meio ambiente (art. 2o, III, Lei 10.257/2001); a justa distribuição dos benefícios e ônus decorrentes do processo de urbanização (art. 2o, IX, Lei 10.257/2001). ${ }^{30}$ A gestão democrática da cidade e sustentabilidade, igualmente incluídas no conteúdo do direito à cidade, serão analisadas nos itens a seguir.

Percebe-se, desta forma, que as orientações jurídico-normativas do direito à cidade conduzem a uma cidade cada vez mais igualitária, inclusiva, participativa e que, para isso, impõe-se uma atuação do poder público, por meio da garantia dos direitos sociais que compõe

\footnotetext{
29 Werneck afirma que a função social da cidade é verdadeira especificação da função social da propriedade (WERNECK, 2007, p. 125).

30 O artigo 20 do Estatuto da Cidade traz uma extensa lista de diretrizes gerais da política urbana.
} 
o direito à cidade, com o estabelecimento de um constante diálogo, previsão de espaços democráticos de gestão urbana e disponibilização de informações.

No entanto, cabe mencionar que há dificuldades em garantir os direitos difusos, que transcendem à lógica dos direitos individuais e rompe com o caráter privatista dos direitos, o que pode ser associado a muitos fatores, podendo-se destacar os relacionados ao acesso aos meios judiciais ou administrativos adequados, interpretação no âmbito do Poder Judiciário, bem como uma variedade de "apropriações sociais - distintos 'projetos ambientais' de atores diversos, com suas pretensões a encarnar direitos difusos" (ACSELRAD, 2008, p. 235-236).

\section{Estrutura jurídica mínima do direito à cidade}

Tomando como ponto de partida o disposto no Estatuto da Cidade, que Ihe confere uma estrutura mínima de direitos, passa-se a uma breve análise do detalhamento do conteúdo jurídico destes direitos: terra urbana, moradia, saneamento ambiental, infraestrutura urbana, transporte e serviços públicos, trabalho e lazer.

O direito à terra urbana, integrante do direito à cidade, está ligado ao valor incalculável da terra, urbana e rural. LIRA afirma que "nele se radicam a fonte de alimentação das gentes, as riquezas criadoras dos instrumentos elementares para a satisfação das incontáveis necessidades vitais, e todo o sistema habitacional dos seres humanos" (LIRA, 1997, p. 108). O mesmo autor lembra que o direito foi previsto na Declaração de Vancouver sobre Assentamentos Humanos, de 1976, em seu princípio 10, nos seguintes termos:

A terra é um dos elementos fundamentais dos assentamentos humanos. Todo Estado tem direito a tomar as medidas necessárias para manter sob fiscalização pública o uso, a propriedade, a disposição e a reserva de terras. Todo Estado tem direito a planejar e administrar a utilização do solo, que é um de seus recursos mais importantes, de maneira que o crescimento dos centros populacionais tanto urbanos como rurais se baseiem num plano amplo de utilização do solo. Essas medidas devem assegurar a realização dos objetivos básicos da reforma social e econômica para cada Nação, de conformidade com o seu sistema e suas leis de propriedade da terra.

A Declaração de Istambul sobre Assentamentos Humanos, produzida pela 2a Conferência Mundial Sobre os Assentamentos Humanos - HABITAT II, em 1996, assenta o compromisso dos estados em trabalhar para "expandir a oferta de moradias a custos acessíveis permitindo que os mercados funcionem com eficiência e de maneira social e ambientalmente responsável, estimulando o acesso à terra e ao crédito e assistindo aqueles que não têm condições de serem atendidos pelo mercado imobiliário" (item 9). 
Para Fiorillo, o direito à terra urbana trata da utilização de parcela do território nas cidades para que se possa "realizar as atividades fundamentais vinculadas às suas necessidades de existência digna dentro da ordem econômica do capitalismo" (FIORILLO, 2004, p. 284).

O direito à terra urbana determina que, de modo justo e igualitário, todos tenham acesso a uma parcela do território para que possam desenvolver atividades fundamentais à vida, com dignidade. De modo a garanti-lo, o Estado deve dispor de meios e instrumentos para fazer sua gestão e fiscalização, voltadas para correção das distorções sociais e econômicas do sistema atual. As ações do Estado devem inserir a variável socioambiental, de modo a garantir que não se aprofundem as desigualdades sociais, utilize de recursos ambientais desnecessários ou que sejam incompatíveis com o atual estágio de esgotamento de certos bens ambientais. Nota-se, ainda, que o direito à terra urbana está vinculado à moradia, trabalho, mobilidade urbana, proteção do meio ambiente, dentre outros direitos constitucionalmente assegurados.

O direito de moradia está previsto no artigo 6ㅇ da Constituição Federal, ${ }^{31}$ bem como na Declaração Universal dos Direitos Humanos, de 1948, e no Pacto Internacional sobre Direitos Econômicos, Sociais e Culturais, de $1966 .{ }^{32}$ Trata-se de "direito humano fundamental à moradia, tomada esta aqui como necessidade humana vital, biológica na sua essência e, por conseguinte, indispensável para uma vida com dignidade" (PORTILHO, 2006, p. 58). Dele derivam outros direitos, como a inviolabilidade de domicílio.

A moradia digna inclui inúmeras políticas públicas que podem e devem ser realizadas pelo poder público, como aprovação de normas para regularização fundiária, alteração de padrões urbanísticos para locais ocupados por população de baixa renda, construção de habitações, delimitação de zonas de especial interesse social. Em relação à discussão sobre direitos sociais, vê-se que algumas destas políticas sequer geram custos para o Estado, cabendo adotá-las dentro do marco da gestão democrática da cidade e da sustentabilidade ambiental. PORTILHO, ao analisar a prática dos Tribunais, afirma que o direito de moradia tem percorrido um tortuoso caminho para sua proteção, não sendo priorizado (PORTILHO, 2006, p. 59).

\footnotetext{
${ }^{31}$ A previsão do direito de moradia no caput do artigo 6o da Constituição Federal ocorreu em 2010, com a Emenda Constitucional 64.

${ }^{32}$ Como visto, alguns dos princípios do Movimento por Reforma Urbana apresentados para a Assembleia Constituinte, relaciona-se à moradia, como o reconhecimento de um direito social de moradia (o que somente ocorreu em 2010), o direito à regularização de assentamentos informais consolidados, a função social da propriedade urbana, bem como o combate à especulação imobiliária nas áreas urbanas. Neste sentido, uma das vitórias relacionadas a tais demandas é o artigo 191 da Constituição Federal, que prevê usucapião para quem, não sendo proprietário de imóvel rural ou urbano, possuir como seu, por cinco anos ininterruptos, sem oposição, área de terra, em zona rural, não superior a cinquenta hectares, tornando-a produtiva por seu trabalho ou de sua família, tendo nela sua moradia.
} 
A luta pela cidade define-se, dentre outras características, pela luta por terra urbana, inclusive em relação ao direito à moradia, o que está relacionado aos serviços e infraestrutura públicos disponíveis no local.

O direito à infraestrutura urbana exige que o poder público, em especial o poder executivo, promova a instalação de equipamentos e execução de obras que garantam infraestrutura adequada a todas as áreas da cidade, como fornecimento de água, tratamento de esgoto, transportes, redes de energia, respeitadas suas características e particularidades. Dentre tais equipamentos e serviços, mencionam-se expressamente os relacionados ao saneamento ambiental, também previsto como um direito que compõe o direito à cidade sustentável. ${ }^{33}$

Fiorillo afirma que o direito ao saneamento ambiental garante aos brasileiros e estrangeiros a "preservação de sua incolumidade físico-psíquica (saúde) vinculada ao local onde vivem" e "dos demais valores vinculados à tutela dos bens ambientais adstritos a determinado meio em que referidas pessoas humanas se relacionam" (FIORILLO, 2004, p. 286). E, nesta seara, estariam incluídos os seguintes direitos fundamentais: ao uso de águas, a esgoto sanitário, ao ar atmosférico e sua circulação, ao descarte de resíduos (FIORILLO, 2004, p. 287). Ao lado da infraestrutura urbana, encontra-se o direito ao serviço público, que está relacionado aos serviços que devem ser prestados pelo poder público e que irão garantir uma vida digna na cidade. ${ }^{34}$ Discussões intensas referem-se ao próprio conceito de serviços públicos e suas possibilidades de privatização.

O Estatuto da Cidade menciona, ainda, o direito ao transporte, mas entende-se que se deve ampliar para tratar da noção de mobilidade urbana, que foi expressamente previsto na Constituição Federal, por meio de recente alteração na Constituição. ${ }^{35}$ Além disso, em setembro de 2015, com a aprovação da Emenda Constitucional 90, introduz-se, expressamente, o

\footnotetext{
${ }^{33}$ A Lei 12.305/2010 estabelece a Política Nacional de Resíduos Sólidos, dispondo sobre seus princípios, objetivos e instrumentos, bem como sobre as diretrizes relativas à gestão integrada e ao gerenciamento de resíduos sólidos, incluídos os perigosos, às responsabilidades dos geradores e do poder público e aos instrumentos econômicos aplicáveis (art. 1으). A Lei 11.445/2007 estabelece diretrizes nacionais para o saneamento básico e para a política federal de saneamento básico.

${ }^{34}$ Não se deve esquecer que o estatuto jurídico dos consumidores (Lei 8.078/1990) equipara usuário de serviço público a consumidor, na medida em que se estabelece que um dos direitos básicos do consumidor é a adequada e eficaz prestação dos serviços públicos em geral (art. 6으, X).

35 Trata-se da Emenda Constitucional 82, de 16 de julho de 2014, que inclui o $\S 10$ ao art. 144 da Constituição Federal, para disciplinar a segurança viária no âmbito dos Estados, do Distrito Federal e dos Municípios, com a seguinte redação: "A segurança viária, exercida para a preservação da ordem pública e da incolumidade das pessoas e do seu patrimônio nas vias públicas", compreendendo "a educação, engenharia e fiscalização de trânsito, além de outras atividades previstas em lei, que assegurem ao cidadão o direito à mobilidade urbana eficiente" (inciso I) (grifou-se).
} 
transporte como direito social. ${ }^{36}$ Direito à mobilidade garante que o acesso universal à cidade, de pessoas e bens, por meio de condições e modos variados de transporte, de modo que se possa viver, trabalhar, desfrutar da cidade, de acordo com as necessidades e desejos pessoais. Em cidades cada vez mais segregadas, ${ }^{37}$ a mobilidade urbana constitui-se como um direito de extrema relevância. Não haverá direito ao trabalho, à saúde, ao lazer, sem transporte público eficiente - o que se relaciona ao direito à infraestrutura urbana e aos serviços públicos - e sem opções viáveis para locomoção das pessoas. ${ }^{38}$

Tal direito igualmente relaciona-se à prestação de serviços públicos de transporte de qualidade e a custos acessíveis, já que restou comprovada a impossibilidade das soluções para mobilidade nas cidades advir de transporte individual motorizado. ${ }^{39}$

Sobre as exigências de atuação do poder público na garantia e proteção dos direitos acima mencionados, não é nenhuma novidade que a administração pública possui o dever de respeitar os princípios constitucionais da legalidade, impessoalidade, moralidade, publicidade e eficiência (art. 37). Especificamente em relação às diretrizes gerais da política urbana, a atuação da administração pública, no que se refere à garantia dos direitos à infraestrutura urbana, à mobilidade, aos serviços públicos, dentre outros, que compõe o direito à cidade, deve:

i. ser permeada pela participação da população e de associações representativas dos vários segmentos da comunidade de forma mais ampla possível;

ii. evitar e corrigir as distorções do crescimento urbano e seus efeitos negativos sobre o meio ambiente;

\footnotetext{
${ }^{36}$ O Brasil possui uma Política Nacional de Mobilidade Urbana, estabelecida pela Lei 12.587/2012, que tem como objetivo "contribuir para o acesso universal à cidade, o fomento e a concretização das condições que contribuam para a efetivação dos princípios, objetivos e diretrizes da política de desenvolvimento urbano" (art. 2ㅇ).

${ }^{37}$ Fernandes, analisando a precariedade das ocupações nas cidades brasileiras, afirma: "Complexo e multidimensional, esse processo de segregação socioespacial deve-se a uma combinação histórica de diversos fatores como as dinâmicas formais e informais do mercado de terras; centralização políticoinstitucional; autoritarismo político-social; burocratização político-administrativa; e corrupção endêmica. De especial importância também tem sido a sobrevivência da estrutura fundiária concentrada e privatista do país; a natureza elitista da incipiente tradição de planejamento urbano; a renovação das práticas seculares de clientelismo político etc" (FERNANDES, 2006, p. 05).

${ }^{38}$ Não se está a afirmar, com este direito, a impossibilidade de se estabelecer qualquer tipo de restrição ao direito de circulação pela cidade, haja vista que muitas destas são estabelecidas como meio de se assegurar outros direitos ou até mesmo o próprio direito à mobilidade.

${ }^{39}$ Neste sentido, lembra-se que o município possui a competência constitucional de "organizar e prestar, diretamente ou sob regime de concessão ou permissão, os serviços públicos de interesse local, incluído o de transporte coletivo, que tem caráter essencial” (art. 30, V).
} 
iii. garantir a oferta de equipamentos urbanos e comunitários, transporte e serviços públicos adequados aos interesses e necessidades da população e às características locais;

iv. estabelecer e respeitar os padrões de produção e consumo de bens e serviços e de expansão urbana compatíveis com os limites da sustentabilidade ambiental, social e econômica do Município e do território sob sua área de influência;

v. promover a justa distribuição dos benefícios e ônus decorrentes do processo de urbanização;

vi. recuperar seus investimentos de que tenha resultado a valorização de imóveis urbanos;

vii. garantir a proteção, preservação e recuperação do meio ambiente natural e construído, do patrimônio cultural, histórico, artístico, paisagístico e arqueológico (art. 2으, Estatuto da Cidade).

A destinação de recursos para tais políticas públicas que exclusivamente atendam à população mais favorecida de uma cidade, agravando a desigualdade social, é inconstitucional por ofensa aos princípios constitucionais da administração pública, além de ofender aos relativos à política urbana, posteriormente detalhados no Estatuto da Cidade. Além disso, não há dúvida que as decisões sobre tais direitos, como mobilidade urbana ou prestação do serviço de tratamento de esgoto urbano, sem a garantia de participação igualmente não atende ao direito à cidade, conforme se analisará a seguir.

Destaca-se, ainda, o direito ao trabalho, como um dos fundamentos da República brasileira relaciona-se aos valores sociais do trabalho e da livre iniciativa (art. 1ㅇ, IV, Constituição Federal). Além da previsão do direito ao trabalho como um dos direitos sociais previstos no artigo 6ㅇ, o dispositivo seguinte traz uma série de direitos dos trabalhadores, urbanos e rurais.

O direito ao lazer relaciona-se à saúde e qualidade de vida, e, portanto, a fundamentos e objetivos da República brasileira, já que não se pode conceber uma vida digna, com bemestar, sem momentos de lazer e descanso. Em relação à cidade, liga-se a existência de espaços destinados a momentos de lazer ou a garantia de adequado transporte para o seu desfrute.

Além destes direitos, passa-se a análise de três aspectos considerados centrais para o direito à cidade: função social da propriedade, gestão democrática e sustentabilidade da cidade. 


\section{A função social da propriedade urbana: superação do paradigma legalista ${ }^{40}$}

O direito à cidade será protegido por meio de uma atuação interventiva do Estado, que deve dispor de instrumentos urbanísticos para a gestão das cidades e limitação dos direitos individuais, especialmente o de propriedade. Importa, assim, o direito de propriedade com conteúdo modificado significativamente pela Constituição Federal de 1988, regida pelos paradigmas da dignidade da pessoa humana, solidariedade e sustentabilidade. Em complemento, as discussões que vêm sendo feitas sobre o próprio direito urbanístico brasileiro refletem, em grande medida, o debate que se deve fazer em relação ao conteúdo do direito à cidade.

O direito urbanístico ${ }^{41}$ possui o "papel de instrumental teórico-metodológico qualificado, para enfrentar as relevantes e urgentes questões inerentes ao processo de interpretação dos espaços urbanos", sendo continuamente interpelado pela garantia do direito à cidade (CAVAlLAZZI, 2007, p. 56). Nas palavras de FernandeS, o "Direito Urbanístico tem um objeto claramente definido e da maior importância, qual seja, promover o controle jurídico dos processos de desenvolvimento, uso, ocupação, parcelamento e gestão do solo urbano" (FERNANDES, 2006, p.12). ${ }^{42}$

FERNANDES destaca alguns princípios do direito urbanístico: princípio do urbanismo como função pública e não apenas como função estatal; supremacia do direito público sobre o direito privado; caráter normativo das regras urbanísticas e a conformidade do direito da propriedade às regras urbanísticas; separação entre o direito de construir e o direito de propriedade; coesão das normas urbanísticas e o da justa distribuição dos ônus e dos benefícios da urbanização (FERNANDES, 2006, p. 12-15). ${ }^{43}$

\footnotetext{
${ }^{40}$ A necessidade de superação do paradigma do legalismo liberal é apontada por Fernandes em diversos trabalhos, indicando, em linhas gerais, que deve se deixar de lado a longa tradição civilista que privilegia os direitos individuais, dentre os quais os relacionados à propriedade urbana, e limita a atuação do Estado na defesa dos interesses difusos e coletivos. Por todos, v. FERNANDES, 2006.

${ }^{41}$ Analisando o estatuto epistemológico do direito urbanístico, Cavallazzi afirma que se trata de um ramo autônomo do direito, que começa a se delinear com a Constituição de 1988 e cuja consolidação tem como marco a aprovação do Estatuto da Cidade (CAVALLAZZI, 2007, p. 53-55). Nesta análise, a autora destaca as práticas sociais, que "cristalizadas em demandas, decerto decorrem do seu próprio objeto nuclear, o direito à cidade" (CAVALLAZZI, 2007, p. 56).

42 Werneck destaca a interdisciplinaridade relacionada ao direito urbanístico, que introduz "uma visão dinâmica da realidade para o intérprete, que atua sobre ela" (WERNECK, 2007, p. 126).

${ }^{43}$ Cavallazzi apresenta os seguintes princípios: função social da propriedade pública e privada; função pública do urbanismo; remissão ao plano; princípio da equidade, do qual derivam a afetação das maisvalias do custo de urbanização e justa distribuição dos benefícios e encargos/ônus decorrentes da
} 
A Constituição Federal permite, assim, a consolidação do direito urbanístico, ${ }^{44}$ enquanto um ramo do direito que estuda e regulamenta função pública que trata de instrumentos reguladores da propriedade urbanística, com base em interesses difusos e pautados em planejamento urbano. O poder público será um dos atores importantes na aplicação das normas urbanísticas, mas, assim como ocorre em relação ao meio ambiente equilibrado, atua como um gestor de interesses difusos, e, neste caso, deve-se voltar à garantia do direito à cidade. ${ }^{45}$ O caráter publicístico do direito urbanístico fica evidente, tendo em vista este ramo "nasce justamente para construir, no tocante à gestão dos bens privados, um sistema decisório complexo, em que o Estado exerce papel preponderante", o que resulta a necessidade de se repensar a propriedade, que está "muito distante da noção civilista clássica, em que a propriedade era tida como simples direito individual" (SUNDFELD, 2006, p.49).

O direito urbanístico justifica-se, dentre outros aspectos, pela conformação do direito de propriedade a interesses e objetivos coletivos, definidos a partir de uma construção social sobre o espaço urbano e regida pelas finalidades de ordenar o pleno desenvolvimento das funções sociais da cidade e garantir do bem-estar de seus habitantes, como determina a Constituição (art. 182). Ou, nas palavras de Cavallazzi, a "cidade, uma vez considerada bem social e espaço público de significação e mediação historicamente construído, impõe ao proprietário do solo o dever de exercer o seu direito em benefício da sociedade" (CAVALLAZZI, 2007, p. 58).

Não há como garantir o direito à cidade, executar planejamento urbano, fazer a gestão das cidades, sem a correspondente imposição de restrições a direitos de propriedade privados e públicos. ${ }^{46} \mathrm{Em}$ outras palavras, a propriedade entendida em seu sentido legalista liberal

atuação urbanística; gestão democrática da cidade; proteção ao meio ambiente; sustentabilidade das cidades; espaço público; paisagem como patrimônio público e precaução (CAVALLAZZI, 2007, p. 63).

${ }^{44}$ Inclusive prevendo a competência legislativa concorrente da União, Estados e Distrito Federal sobre direito urbanístico (art. 24, I).

${ }^{45}$ Não há contradição entre considerar espaços públicos como bens comuns, entender o direito à cidade como um direito intrinsecamente ligado ao poder de decidir e viver a cidade e exigir-se do Estado, leia-se poder público, uma atuação interventiva em relação aos direitos individuais ou o próprio cumprimento da função social da propriedade. O Estado continuará existindo e deve exercer um papel relevante em relação a garantia do direito à cidade, por exemplo, por meio da imposição de limitações ao direito de propriedade, executando os instrumentos que estão postos à sua disposição, no sentido de concretizar os desejos e decisões dos habitantes da cidade.

${ }^{46}$ Importa apenas destacar aqui lição de Di Pietro, que estuda esta noção justamente relacionada ao direito urbanístico e determinações do Estatuto da Cidade. A autora afirma que o princípio da função social da propriedade pública está ligado ao artigo 182 da Constituição Federal, na medida em que impõe um dever ao poder público e "cria para os cidadãos direito de natureza coletiva de exigir o cumprimento da norma constitucional” (DI PIETRO, 2006, p. 03). 
constitui um impeditivo à concretização do direito à cidade. Do ponto de vista teórico há um inegável avanço no tratamento do direito de propriedade em relação à consideração de interesses alheios aos do proprietário. ${ }^{47}$ Diz-se que o direito de propriedade, um dia considerado o direito absoluto por excelência, tem seu conteúdo definido por condições históricas - e nas cidades brasileiras será definido pelas democráticas decisões de seus habitantes. ${ }^{48}$

No Brasil, há regras constitucionais específicas sobre o tema. O proprietário rural deve não somente observar seus interesses egoísticos, mas, por exemplo, a garantir a adequada utilização dos recursos naturais disponíveis e preservação do meio ambiente, no caso de imóveis rurais (art. 186). Em relação às cidades, a Constituição Federal brasileira, que atendeu a diversas demandas dos movimentos pela reforma urbana, condicionou o direito de propriedade ao cumprimento da sua função social, que corresponde ao atendimento das "exigências fundamentais de ordenação da cidade expressas no plano diretor" (182, §2ำ). ${ }^{49} 50$

\footnotetext{
${ }^{47}$ Tepedino e Schreiber afirmam que a noção de função social da propriedade "encontra-se de tal forma consolidada na experiência brasileira dos últimos anos, que não há dúvidas de que a garantia da propriedade não pode ser mais vista à parte de sua conformação aos interesses sociais. Em outras palavras: não há, no texto constitucional brasileiro, garantia à propriedade, mas tão-somente garantia à propriedade que cumpre a sua função social" (TEPEDINO; SCHREIBER, 2005, p. 105). E, neste sentido, entendem que a função social compõe o próprio conteúdo do direito de propriedade - não sendo um elemento externo: "a função social é, antes, capaz de moldar o estatuto proprietário em toda a sua essência, constituindo, como sustenta a melhor doutrina, o título justificativo, a causa, o fundamento de atribuição dos poderes ao titular" (p. 106).

48 Afirma Werneck: "[...] é de reportar ao célebre trocadilho de Salvatore Pugliatti, La Proprietá, Le Proprietá", ao propor a ideia de propriedades como resultado da diversa função social que pode ser atribuída aos bens, notadamente aos bens imóveis. Toda uma geração de civilistas e urbanistas italianos, intérpretes do Código Civil de 1966, consolida um novo perfil do instituto da propriedade, percebida desde então no marco do direito constitucional, com a função social da propriedade sendo identificada como uma inerência, um dado intrínseco que supera o procedimento ou limitação meramente negativa, circunstancial, para dotar de eficácia positiva as disposições que concretizem o direito de propriedade e, ao mesmo tempo, assim, sua função social" (WERNECK, 2007, p. 124).

${ }^{49}$ Analisando os princípios que orientam a reforma jurídico-urbanística no Brasil, Fernandes afirma: "O mais importante desses princípios é certamente o da função socioambiental da propriedade e da cidade, que por sua vez é uma expressão do princípio de que o urbanismo é uma função pública no sentido mais amplo, isto é, a ordem urbanística não é determinada tão-somente pela ordem dos direitos individuais, não sendo reduzível tão somente à ordem dos interesses estatais. Trata-se na verdade de uma noção antiga e já repetida em várias constituições brasileiras, mas que, pela primeira vez, na Constituição de 1988, e especialmente com a aprovação do Estatuto da Cidade, se tornou uma noção consistente e não uma mera figura de retórica sobretudo na medida em que esse princípio se traduz, na ordem constitucional brasileira em direitos coletivos novos e inter-relacionados" (FERNANDES, 2006, p. 11).

${ }^{50} \mathrm{O}$ artigo 5o, XXII e XXIII, assegura o direito de propriedade, condicionado ao cumprimento de uma função social, e o artigo 170, II e III, inclui a propriedade e sua função social como princípios da ordem econômica.
} 
TRINDADE entende que o direito à cidade é mais amplo e complexo que o de moradia, já que "considera a localização do indivíduo no sistema urbano em seu conjunto e a possibilidade de acesso às melhores localizações da cidade" e, ao trabalhar o conceito na sociedade capitalista, afirma a necessidade de atuação do Estado na formulação de políticas públicas que garantam estas condições igualmente para as camadas mais vulneráveis da sociedade. Por isso, o autor analisa que, do ponto de vista jurídico, direito à cidade está vinculado ao princípio da função social da propriedade, "justamente com o intuito de regular o uso da propriedade e do solo urbano, coibindo assim a prática da especulação imobiliária" (TRINDADE, 2012, p. 149). ${ }^{51}$

Como dito, a propriedade terá seu conteúdo definido a partir do paradigma da gestão democrática da cidade. O plano diretor fixará as condições e requisitos para que o direito de propriedade atenda à sua função social..$^{52} \mathrm{O}$ direito de propriedade poderá ter seu conteúdo bastante diferente, a depender da cidade, bairro ou outras características decididas pelos habitantes das cidades no processo de elaboração do plano diretor. ${ }^{53}$ O direito de propriedade será definido por um processo político (FERNANDES, 2006, p. 14). ${ }^{54}$ E, neste sentido, há uma relação intrínseca entre a função social da propriedade e a gestão democrática da cidade, com

\footnotetext{
${ }^{51}$ Além da função social da propriedade, o autor vincula o direito à cidade à sua gestão democrática, prevista na Constituição Federal e no Estatuto da Cidade, conforme igualmente será destacado no item seguinte (TRINDADE, 2012, p. 152).

52 Os planos diretores são leis especiais "tanto pelo aspecto da constitucionalização de seu objeto principal - a definição de função social da propriedade urbana -, como pela abrangência da matéria e da diversidade de normas que o integram, desde princípios e diretrizes até regras que irão criar no âmbito municipal instituições do Estatuto da Cidade [...] e inspirar topicamente o uso e ocupação do solo", além de tratar da disciplina da gestão democrática da cidade (WERNECK, 2007, p. 133-134).

${ }^{53}$ É sabido, contudo, que a elaboração e implementação dos planos diretores sofre com limitações advindas das estruturas políticas, econômicas e sociais. Santos Junior e Montandon afirmam que pesquisa sobre balanço dos Planos Diretores, realizada em 2011, parece confirmar o mesmo diagnóstico realizado em relação a novas e velhas práticas das políticas urbanas: "As primeiras são impulsionadas por uma nova cultura vinculada tanto a dimensão dos direitos sociais inscritos na Constituição de 1988 e no Estatuto da Cidade quanto a participação de uma pluralidade de atores sociais com presença na cena pública. Já as velhas práticas se ligam a cultura conservadora e aos paradigmas tecnocráticos que ainda vigoram em muitos municípios brasileiros". Em linhas gerais, a pesquisa demonstra "generalizada incorporação dos instrumentos previstos no Estatuto da Cidade pelos municípios" e "que o plano diretor foi amplamente elaborado pelos municípios, indicando o efeito das ações do Ministério das Cidades na sensibilização e mobilização de gestores públicos e da sociedade. Ao mesmo tempo, do ponto de vista qualitativo, nem todos os Planos Diretores são efetivamente resultado de um pacto social para a gestão" (SANTOS JUNIOR; MONTANDON, 2011, p. 27-28).

54 A exigência constitucional de elaboração do plano diretor para cidades com mais de vinte mil habitantes (art. 182) faz como que FERNANDES afirme a existência de um direito coletivo ao planejamento das cidades ("direito de todos terem suas cidades planejadas em processo de ordenamento territorial definido de acordo com critérios econômicos e socioambientais") (FERNANDES, 2006, p. 11).
} 
destaque para os instrumentos de democracia direta, e não somente para a elaboração do plano, mas seu controle e execução (WERNECK, 2007, p. 132).

Os direitos de propriedade, entendidos com as limitações impostas pelo democrático processo de elaboração do plano diretor, são centrais para a garantia do direito à cidade. E não somente seu conteúdo será determinado por um processo político, mas a aplicação das normas que configuram o direito de propriedade (e em consequência o próprio direito à cidade) constituem-se como um constante processo permeado por disputas e conflitos.

\section{Gestão democrática como elemento integrante do direito à cidade}

A gestão democrática da cidade encontra-se no cerne do direito à cidade, a partir da obra de Lefebvre, que o veicula à uma cidade em direção ao verdadeiros desejos e necessidades dos seus habitantes, ligado aos projetos utópicos, que poderão um dia concretizar-se, mas que delimitam uma ampla e irrestrita participação dos que habitam e vivem na cidade; e igualmente como Harvey, que entende o direito à cidade como um poder de transformação. Não há, assim, como entender o direito à cidade sem incluir os direitos à participação, com real poder de decisão, à informação e à publicidade.

RIBEIRO e SANTOS JUNIOR destacam a participação e deliberação da coletividade urbana sobre seus destinos como elementos integrantes do direito à cidade, que deve ser voltado a assegurar riqueza social a todos. O direito à cidade é o direito à participação nos processos deliberativos, à adoção do universalismo de procedimentos "como padrão de deliberação da coletividade urbana sobre seus destinos" e à universalidade no "acesso à riqueza, à renda e às oportunidades geradas no (e pelo) uso e ocupação do solo urbano" (RIBEIRO; SANTOS JUNIOR, 2011, p. 12).

Há exigência de elaboração e aprofundamento dos meios e instrumentos de participação direta como concretização do direito à cidade, vez que impossível formular e concretizar um novo projeto de cidade nos moldes tradicionais de democracia representativa. A condução direta da cidade, especialmente por meio da tomada de decisões cruciais para sua definição, pressupõe a centralidade dos habitantes por meio de processos de participação, formulação de políticas públicas e, inclusive, pela autogestão de bens e serviços urbanos. FERNANDES afirma a necessidade de um novo contrato político, ainda mais se considerado o estágio atual de crise das representações:

A formulação e materialização de um novo contrato político de cidadania social, reconhecendo e legalizando os direitos dos cidadãos em participar 
plena e ativamente na sociedade política e civil, constitui condição sine qua non para expansão e aprofundamento da democracia (FERNANDES, 2007, p.206, tradução livre).

Neste sentido, cabe lembrar as manifestações ocorridas no Brasil em 2013, que se iniciaram a partir da discussão sobre transporte urbano nas cidades, ${ }^{55}$ especificamente o valor da passagem de ônibus, a eficiência do serviço, a transparência das planilhas orçamentárias das empresas e o caráter público do serviço de transporte público. ${ }^{56}$ Não se pode negar, assim, uma clara vinculação inicial com o direito à cidade, ${ }^{57}$ sendo certo que as pautas apresentaram uma grande diferenciação com o passar do tempo. ${ }^{58}$ Estas manifestações levantaram discussões sobre a crise de representatividade política no Brasil, determinando, inclusive, a apresentação de uma proposta de reforma política que poderia incluir uma nova assembleia constituinte. Muitos trabalhos analisam estas manifestações, e, claro, não há consenso; há um largo espaço para discussão. No entanto, pode-se entender que ao menos parte destas manifestações encontra-se vinculada ao direito à cidade, à crise ética e política das instâncias constituídas e à insatisfação na vida urbana, especialmente das grandes cidades.

Na mesma linha da conexão do direito à cidade com as possibilidades de participação efetiva da população na gestão e na construção da cidade, Alfonsin et al afirma que o "envolvimento e o engajamento dos indivíduos no espaço em que habitam são essenciais para a concretização dos seus direitos de cidadania e, consequentemente, para a realização de uma cidade efetivamente democrática" (ALFONSIN et al, 2015, p. 85).

\footnotetext{
55 Vainer analisa que o contexto dos investimentos relacionados à Copa do Mundo, 2014, e Olimpíadas, no caso do Rio de Janeiro, 2016, serviu para intensificar as "diferenciadas, dispersas e fragmentadas manifestações de protesto, a insatisfação e resistência", que se multiplicavam nas cidades (VAINER, 2013, p. 36).

${ }^{56}$ Nas palavras do Movimento Passe Livre, "se a retomada do espaço urbano aparece como objetivo dos protestos contra a tarifa, também se realiza como método, na prática dos manifestantes, que ocupam as ruas determinando diretamente seus fluxos e usos. A cidade é usada como arma para sua própria retomada: sabendo que o bloqueio de um mero cruzamento compromete toda a circulação, a população lança contra si mesma o sistema de transporte caótico das metrópoles, que prioriza o transporte individual e as deixa à beira de um colapso" (MOVIMENTO PASSE LIVRE, 2013, p. 16).

${ }^{57}$ Como afirma Alfonsin et al, "a agenda da redução da tarifa traz em seu bojo a questão do direito que os cidadãos e cidadãs têm à liberdade de circulação pela cidade, ao direito de ir e vir bem como a desfrutar do espaço público como bem coletivo. Quando a passagem de ônibus é muito cara, é o próprio direito à cidade que se torna uma mercadoria" (ALFONSIN et al, 2015, p. 74).

${ }^{58}$ Souza apresenta que a mobilização, a princípio, gravitou em torno do Movimento Passe Livre (MPL), que tem como pauta o "passe livre nos transportes coletivos, passou-se rapidamente a um desdobramento sociopolítico que não expressa outra coisa que uma enorme energia social reprimida. A agenda inicial, socialmente crítica e inclusive anticapitalista, introduzida pelo MPL, foi sendo obscurecida e parcialmente escondida por uma agenda muito mais ampla e amorfa do ponto de vista ideológico" (SOUZA, 2013, p. 105, tradução livre).
} 
O Estatuto de Cidade tem como um de seus eixos a gestão democrática, inserindo-a, desde logo, como uma de suas diretrizes, "por meio da participação da população e de associações representativas dos vários segmentos da comunidade na formulação, execução e acompanhamento de planos, programas e projetos de desenvolvimento urbano" (art. 2으, II, Lei 10.257/2001). ${ }^{59}$ Além disso, possui um capítulo com os instrumentos voltados para esta gestão, contando com órgãos colegiados de política urbana, nos níveis nacional, estadual e municipal; debates, audiências e consultas públicas; conferências sobre assuntos de interesse urbano, nos níveis nacional, estadual e municipal; ${ }^{60}$ iniciativa popular de projeto de lei e de planos, programas e projetos de desenvolvimento urbano (art. 43). ${ }^{61} 62$

\section{Sustentabilidade das cidades como um direito fundamental}

A indissociável relação entre direitos fundamentais à cidade e meio ambiente ecologicamente equilibrado, que o Estatuto da Cidade entendeu por bem denominar de direito a cidades sustentáveis, ${ }^{63}$ não pode ser negligenciada. A natureza dos bens, garantias e direitos envolvidos exige que se considere, de modo integrado, estas duas questões.

As pautas sobre meio ambiente e cidades estão cada vez mais próximas. Moradia, saneamento ambiental, resíduos sólidos, mobilidade são temas que podem servir como exemplos da relação indissociável entre meio ambiente e cidade. Fernandes afirma que a

\footnotetext{
${ }^{59}$ A gestão democrática das cidades envolve a participação dos cidadãos e habitantes "nas funções de direção, planejamento, controle e avaliação das políticas urbanas" e conduz a um novo pacto territorial, no qual o direito garanta a cidade como um espaço para todos os habitantes (BUCCl, 2006, p. 336).

${ }^{60}$ As Conferências da Cidade, que veiculavam grande otimismo dos envolvidos, foram perdendo força e entusiasmo ao longo dos anos. Entre a primeira e segunda Conferência, realizada em 2003 e 2005, respectivamente, e as seguintes, nota-se uma diminuição de expectativa e envolvimento.

${ }^{61}$ Foi vetada a previsão de referendo popular e plebiscito como um dos instrumentos de gestão democrática. A justificativa do veto foi no sentido de que a Lei 9.709/1998 já previa a realização destas e que não observaria a boa técnica legislativa esta nova previsão em uma Lei diferente.

${ }^{62}$ ACSELRAD trabalha o conceito de ambientalização truncada do Estado brasileiro para denotar a "ausência, neste caso, de base social capaz de fazer representar no interior do Estado a perspectiva dos que recusam a inelutabilidade das políticas de apoio a uma acumulação intensiva em território e recursos ambientais". Esta resultou em uma participação igualmente truncada, na medida em que, na saída do regime ditatorial, adotou-se um discurso participativo, "apropriando-se da conjuntura da democratização, mas sempre considerado pouco efetivo no que diz respeito à capacidade de influência das ONGs que lá supõe-se representar a perspectiva da sociedade" (ACSELRAD, 2008, p.229-230).

${ }^{63}$ Mesmo diante da referência expressa do direito a cidades sustentáveis, opta-se, nesta pesquisa, por adotar a expressão direito à cidade, por uma ligação mais imediata aos aspectos sociais e políticos analisados anteriormente, especialmente diante do poder de modificação da cidade e determinar os destinos da cidade. Não há, contudo, prejuízo ao conteúdo do direito, já que, conforme será apresentado neste item, entende-se que o caráter da sustentabilidade, mesmo que com significados em constante disputa, inclui-se no conteúdo do direito à cidade.
} 
Agenda 21 e Agenda Habitat partiram para um enfoque integrado entre meio ambiente e desenvolvimento, expresso no conceito de desenvolvimento sustentável, "que reconhece que as questões ambientais estão intrinsecamente ligadas aos processos socioeconômicos de desenvolvimento" e, especificamente em relação à segunda, reconhece-se que as "cidades não são apenas os loci de problemas sociais, ambientais e econômicos únicos, mas também oferecem oportunidades únicas para a criação das bases de um futuro mais sustentável" (FERNANDES, 2004, p.297).

Cardoso afirma que o desenvolvimento sustentável, introduzido pelo Relatório Brudtland, ou "Nosso Futuro Comum", de 1988, no qual se pretende compatibilizar desenvolvimento econômico com proteção ambiental, indicando a tarefa de "atender às necessidades e aspirações do presente sem comprometer a possibilidade de atendê-las no futuro", teve um papel importante na redefinição das relações entre cidade e meio ambiente:

Não se trata mais de uma questão do desenvolvimento, como na década de 70, mas de uma questão ambiental. Além disso, ao estabelecer a ideia de sustentabilidade como paradigma de um novo modelo de desenvolvimento, o Relatório cria uma alternativa nova para se pensar o processo de urbanização, um novo modelo para orientar o desenvolvimento urbano. É possível, daí em diante, pensar em "cidades sustentáveis", como padrão normativo para a avaliação das cidades existentes e como visão de futuro a orientar as escolhas presentes (CARDOSO, 2011, p. 55).

Acselrad reflete que há um duplo movimento. A ambientalização do debate sobre políticas urbanas, por meio da qual os atores procuram legitimar "suas perspectivas, evidenciando a compatibilidade das mesmas com os propósitos de dar durabilidade ao desenvolvimento". E a inserção das questões urbanas no debate ambiental, "seja por iniciativa de atores sociais da cidade que incorporam a temática do meio ambiente [...], seja pela própria trajetória de urbanização crescente da carteira ambiental dos projetos do Banco Mundial" (ACSELRAD, 2009a, p. 53). Além disso, o autor nota que a "cidade sustentável" entra, ainda, como estratégia de venda da cidade no mercado global (ACSELRAD, 2009a, p. 53), tal como se mencionou, na introdução deste livro, em relação aos conceitos vagos.

O padrão de urbanização brasileiro, que não se diferencia de outras partes do mundo, intensifica desigualdades sociais no Brasil, inclusive por meio da distribuição diferenciada da degradação ambiental, que afeta a população de baixa renda de modo mais intenso. Além disso, não se pode esquecer que a cidade é um dos palcos mais evidentes da degradação ambiental e com intensa capacidade de afetar um extenso número de pessoas. 
O direito à cidade não pode ser visto de modo independente das condições ambientais existentes:

a busca da promoção de desenvolvimento sustentável tem de ser baseada na noção mais ampla do direito à cidade, a ser compreendido e aplicado tanto como norma jurídica como enquanto princípio sociopolítico guiando os processos socioeconômicos e políticoinstitucionais que visam promover a redução das desigualdades, eliminar a discriminação e resolver conflitos sobre o uso e usufruto de recursos naturais, tais como a terra urbana e a água (FERNANDES, 2004, p. 303).

Molinaro afirma que o direito à cidade é um direito fundamental que decorre do caráter socioambiental a que adere o país em sua Carta Constitucional. Todos os direitos e garantias fundamentais relacionados ao direito à cidade, como os mencionados na Lei 10.257/2001, decorrem do regime e princípios constitucionais. E conclui, comparando com o direito fundamental ao meio ambiente ecologicamente equilibrado, "o direito à cidade nele contido, também se revela como um direito entre gerações, inclusivo e social. Ademais e pela mesma razão, dá ensejo ao exercício pleno da cidadania e aos pertinentes deveres cometidos ao poder público" (MOLINARO, 2009, p. 25).

E, como afirma Alfonsin, a "cidade marcada pela desigualdade social e pela exclusão territorial não é capaz de produzir um desenvolvimento sustentável" (ALFONSIN, 2001, p. 314). Cavallazzi igualmente destaca o caráter inclusivo, afirmando que o "grande projeto da cidade sustentável" pode ser traduzido como "a garantia constitucional da qualidade de vida para todos os cidadãos" (CAVALLAZZI; AGUIAR, 2012, p.131).

Regido pela Constituição Federal de 1988, o Estatuto da Cidade passa a tratar de direito à cidade sustentável, relacionando-se diretamente à garantia de se assegurar os direitos envolvidos às presentes e futuras gerações. E a dimensão da sustentabilidade encontra-se presente não somente nesta referência expressa, mas em outros dispositivos da Lei 10.257/2001, cabendo mencionar a exigência de "planejamento do desenvolvimento das cidades, da distribuição espacial da população e das atividades econômicas do Município e do território sob sua área de influência, de modo a evitar e corrigir as distorções do crescimento urbano e seus efeitos negativos sobre o meio ambiente" (art. 2으, IV), "ordenação e controle do uso do solo, de forma a evitar a poluição e a degradação ambiental" (art. 2o, VI, g), "proteção, preservação e recuperação do meio ambiente natural e construído, do patrimônio cultural, histórico, artístico, paisagístico e arqueológico" (art. 2ํㅡ, XII). ${ }^{64}$

\footnotetext{
${ }^{64}$ Fiorillo afirma que a garantia do direito a cidades sustentáveis estabelece "um patamar de direitos metaindividuais destinados a brasileiros e estrangeiros residentes no País dentro de uma perspectiva de
} 
Não se entende a questão ambiental por meio de seus aspectos exclusivamente físicos ou biológicos, mas integrando os aspectos sociais. No direito brasileiro, inclusive, não há dúvida em relação ao tema, já que, por meio de uma interpretação sistemática da Constituição Federal e dos conceitos trazidos pela Lei da Política Nacional de Meio Ambiente, pode-se concluir que meio ambiente inclui aspectos sociais e culturais. ${ }^{65} 66$

O direito à cidade, com seu caráter relacionado à sustentabilidade incluído, integra-se, assim, imediatamente, aos objetivos gerais de solidariedade, erradicação da pobreza e da marginalização social e redução das desigualdades sociais e regionais da República Federativa do Brasil, previstos no artigo 3ำ da Constituição Federal, além do direito fundamental ao meio ambiente ecologicamente equilibrado (art. 225).

Tratando da inserção da solidariedade e dos outros objetivos acima mencionados, Bodin de Moraes afirma que "o projeto de um sociedade livre, justa e solidária contraria a lógica da competição desmedida e do lucro desenfreado [...]", que foi,

por determinação constitucional, substituída pela perspectiva solidarista, em que a cooperação, a igualdade substancial e a justiça social se tornam valores hierarquicamente superiores, subordinados tão somente ao valor precípuo do ordenamento, que está contido na cláusula de tutela da dignidade da pessoa humana (BODIN DE MORAES, 2010, p. 264).

E, como a própria autora afirma, o princípio fundamental do ordenamento é a dignidade da pessoa humana e que será concretizado a partir da ponderação entre os valores

tutela do meio ambiente artificial que sem dúvida alguma procura realizar os objetivos do Estado democrático de direito" (FIORILLO, 2004, p. 291). A questão referente ao meio ambiente artificial será analisada no tópico que trata da sustentabilidade das cidades como um direito.

${ }^{65} \mathrm{Na}$ Constituição Federal, o capítulo que trata da proteção do meio ambiente está inserido dentro do título da ordem social.

A Lei da Política Nacional do Meio Ambiente (Lei 6.938/1981) deve ser interpretada sistematicamente em relação aos conceitos trazidos no artigo 3으, que, dentre seus dispositivos, define meio ambiente como "o conjunto de condições, leis, influências e interações de ordem física, química e biológica, que permite, abriga e rege a vida em todas as suas formas" (inciso I), degradação da qualidade ambiental como a "alteração adversa das características do meio ambiente" (inciso II), poluição como a degradação da qualidade ambiental resultante de atividades que direta ou indiretamente: prejudiquem a saúde, a segurança e o bem-estar da população; criem condições adversas às atividades sociais e econômicas; afetem desfavoravelmente a biota; afetem as condições estéticas ou sanitárias do meio ambiente; lancem matérias ou energia em desacordo com os padrões ambientais estabelecidos (inciso III). No mesmo sentido, tem-se a Resolução CONAMA 01/86, que trata de impacto ambiental.

${ }^{66}$ Fernandes afirma que a dificuldade de aplicação prática da ampliação do conceito de impacto ambiental, passando de critérios meramente naturalistas e a-espacial, para uma noção que abarque aspectos sociais e econômicos, pode ser apontada como uma das dificuldades na interação entre o que denominou de agenda marrom e agenda verde. Sobre a limitação, exemplifica: "não basta identificar os problemas ambientais decorrentes do uso de automóveis, é preciso compreender a lógica dos processos de desenvolvimento, uso e ocupação do solo urbano que permitem a expansão do sistema de transporte baseado em automóveis" (FERNANDES, 2004, p. 310-311). 
da liberdade e da solidariedade, o que será feito em cada caso, a depender da disponibilidade ou não dos interesses envolvidos (BODIN DE MORAES, 2010, p. 264-265).

Além disso, o direito fundamental ao meio ambiente ecologicamente equilibrado está em sintonia com a noção de pleno desenvolvimento da personalidade humana, entendendo-o como diretamente vinculada à redução das desigualdades sociais, erradicação da pobreza, bem como ao direito à saúde e vida digna. ${ }^{67}$ Sarlet afirma-se tratar da dimensão ecológica da dignidade da pessoa humana, que exige uma vida digna, saudável e segura, ou seja, seria preciso um patamar mínimo de qualidade ambiental para concretizar a dignidade da pessoa humana (SARLET; FENSTERSEIFER, 2012, p.40), o que evidencia a interdependência e indivisibilidade entre os direitos e, no caso, a importância do meio ambiente ecologicamente equilibrado para outros direitos fundamentais. ${ }^{68}$

A proteção do meio ambiente, pela Constituição Federal de 1988, é considerada como um dos valores edificantes do Estado Democrático de Direito brasileiro, marcado pelo comprometimento com a garantia da qualidade de vida, saúde, condições dignas de sobrevivência. Neste sentido, a norma constitucional afirma o direito de todos ao meio ambiente ecologicamente equilibrado, o configura como bem de uso comum do povo e essencial à sadia qualidade de vida, além de estabelecer o dever do poder público e da coletividade de defendê-lo e preservá-lo para as presentes e futuras gerações (artigo 225).

A Constituição Federal, que possui um caráter de transformação social e de instrumento de implementação de políticas públicas (PIOVESAN, 2011, p. 63), iniciou a construção, no Brasil, de um constitucionalismo ecológico (BENJAMIN, 2007), ou Direito Constitucional Ambiental (SILVA, 2013; SARLET, FENSTERSEIFER, 2012). ${ }^{69}$

A partir da atribuição ao poder público de proteger o meio ambiente, tem-se a solidificação teórica de Estado socioambiental de Direito,

que, em verdade, não abandona as conquistas dos demais modelos de Estado de Direito em termos de salvaguarda da dignidade humana, mas

\footnotetext{
67 "A análise fragmentada do direito ao meio ambiente implicará equívocos, posto que o direito ao meio ambiente interage acentuadamente com o direito à vida e à saúde, ambos direitos invioláveis. Ainda nesta perspectiva multidisciplinar, verifica-se que o direito ao meio ambiente interage também com a função social da propriedade e com o planejamento, à medida que não há efetividade do direito ao meio ambiente sem que existam políticas públicas ambientais, integradas em um planejamento urbanístico" (PIOVESAN, 2011, p. 66).

${ }^{68}$ Em relação à importância para outros direitos fundamentais, "todos os direitos humanos constituem um complexo integral, único e indivisível, em que os diferentes direitos estão necessariamente interrelacionados e interdependentes entre si" (PIOVESAN, 2011, p. 63).

${ }^{69}$ Silva afirma "A Constituição de 1988 foi, portanto, a primeira a trata deliberadamente da questão ambiental. Pode-se dizer que ela é uma Constituição eminentemente ambientalista" (SILVA, 2013, p. 49).
} 
apenas agrega a elas uma dimensão ecológica, comprometendo-se com a estabilização e prevenção do quadro de riscos e degradação ecológica (SARLET; FENSTERSEIFER, 2012, p. 44, grifos dos autores). ${ }^{70}$

Não se pretende afirmar, contudo, que a aplicação ou garantia do direito ao meio ambiente ecologicamente equilibrado ocorre de modo uniforme, universal e democrático. Deve-se colocar em discussão os reflexos das desigualdades geradas e intensificadas pelo desequilíbrio ambiental e à própria divergência de conteúdo dado ao mencionado direito, ${ }^{71}$ a depender dos atores envolvidos. Os desastres ambientais, as consequências negativas oriundas de desrespeito ao equilíbrio do meio ambiente, dentre outros fenômenos, não são democráticas, tendendo a alcançar os grupos e indivíduos pertencentes a classes menos favorecidas da sociedade. ${ }^{72}$ Este aspecto não democrático da questão ambiental foi incorporado pelo movimento de justiça ambiental, que o articulou com as lutas por justiça social (ACSELRAD, 2009b, p. 15).

As constantes comprovações de que grupos sociais economicamente menos favorecidos - ou grupos vulneráveis - suportam parcela desproporcional das consequências ambientais negativas de operações econômicas, decisões de políticas e programas federais,

\footnotetext{
70 É importante destacar, contudo, a necessidade de a ciência jurídica acompanhar o debate do Estado Ambiental, que traz uma conotação de limitação das liberdades individuais, pois, como denota Kloepfer, "uma proteção do meio ambiente não juridicamente determinada, todavia, aumentaria o risco de decisões arbitrárias em atividades relativas ao meio ambiente e, no final das contas, destruiria o sistema político da democracia libertária do Estado de direito. É preciso impedir essa evolução, porque a qualidade de vida não é determinada apenas por meio ambiente digno, mas também por um sistema político humano" (KLOEPFER, 2010, p. 71-72).

${ }^{71}$ OST afirma que "incerto nos seus fundamentos e contraditório no seu conteúdo, o direito do ambiente conhece igualmente uma aplicação hesitante. A ausência de uma escolha clara e de uma prioridade distintamente fixada, conduz à alteração dos textos, ao seu torneamento, e mesma à sua distorção [...] 0 direito do ambiente seria, assim, comparável a uma tapeçaria de Penélope, em que o que é feito num dia é subrepticiamente desfeito no outro? É forçoso constatar que, pelo menos em alguns sectores, essa conclusão se impõe" (OST, 1995, p. 127 e 132). Neste aspecto é importante lembrar que não apenas o conteúdo do direito está em disputa, mas igualmente a edição das normas ambientais e sua aplicação. A aplicação da legislação ambiental sempre foi objeto de grande disputa, envolvendo a possibilidade de conformação dos preceitos estabelecidos na legislação pelo órgão ambiental ou até mesmo de alteração da legislação, abrandando-se restrições ao desenvolvimento de atividades, de modo a possibilitar sua instalação, processo este baseado em uma decisão política prévia à análise dos impactos ambientais e sem a participação de outros grupos - justamente os considerados minoritários e que serão mais afetados. Por outro lado, a edição - ou alteração - das normas relacionadas ao meio ambiente tem sido disputada ainda mais intensamente. Como exemplo, tem-se o processo de alteração da Lei federal 4.771/1965, que institui o Código Florestal brasileiro, e a proposta de emenda constitucional 215, que pretende passar para o Congresso Nacional a atribuição de demarcação de terras indígenas e titulação de terras quilombolas, regulando, ainda, a atividade de mineração naqueles locais.

72 Bullard afirma que o "racismo ambiental é uma forma de discriminação institucionalizada. A discriminação institucional é definida como 'ações ou práticas conduzidas pelos membros dos grupos (raciais ou étnicos) dominantes com impactos diferenciados e negativos para os membros dos grupos (raciais ou étnicos) subordinados" (BULLARD, 2004, p.43).
} 
estaduais, locais, bem como da ausência ou omissão de tais políticas, como dito, deu origem ao que se denomina de injustiça ambiental (ACSELRAD, 2009b, p.41).

Não se pode negar, contudo, que o termo sustentabilidade é um conceito vazio, a ser disputado nos debates técnicos e políticos (CARDOSO, 2011, p. 55). Acselrad analisa os diversos significados que vem se dando aos conceitos de sustentabilidade, destacando que a busca por um conceito unânime, que legitime as políticas urbanas, notadamente alegadas com base na técnica e eficiência, "justifica-se, por certo, pela necessidade e de prevenção dos riscos de ruptura sociopolítica em cidades crescentemente fragmentadas pelos processos de globalização e acumulação flexível" (ACSELRAD, 2009a, p. 68). Importante destacar que, dentre estes significados, parece prevalecer o que reduz à dimensão material, "que tende a desconsiderar a dimensão política do espaço urbano, desconsiderando a complexidade da trama social responsável tanto pela reprodução como pela inovação na temporalidade histórica das cidades" (ACSELRAD, 2009a, p. 66).

Esta discussão é especialmente relevante no âmbito do Direito, que tende a tratar da questão da sustentabilidade como uma categoria universal e não questionável, quando, na verdade, aplicam-se normas com base em juízos de cunho político e ideológico. ${ }^{73} \mathrm{~A}$ sustentabilidade pode ser alegada para remover comunidades em áreas de encostas e para legitimar a permanência de condomínios de alto luxo igualmente em áreas protegidas. Ou o mesmo conceito pode ser usado para permitir a continuidade do uso do amianto crisotila ou para proibir sua utilização em todo território nacional.

No entanto, mesmo diante desta disputa e da pluralidade de possíveis significados, e com a constante necessidade de se afirmar a politização desta definição, entende-se que a sustentabilidade está inserida no conteúdo do direito à cidade, tanto por meio da solidariedade, expresso na própria configuração deste direito pelo Estatuto, quanto pelo caráter indissociável dos aspectos ambientais para garantia dos direitos sociais e difusos que integram o direito à

\footnotetext{
73 Pode-se entender, com Coutinho, que a "sustentabilidade" das cidades no capitalismo é uma ilusão, entendendo que a "crise urbana" é uma feição da "ordem determinada pela lógica do capital" (COUTINHO, 2007, p. 45, grifos do autor).

Em outros casos, tenta-se, no Direito, definir cidades sustentáveis, o que pode acabar na utilização de termos igualmente abstratos e abertos, o que pode denotar a dificuldade apontada para definir teoricamente o conceito. Oliveira, por exemplo, afirma que cidades sustentáveis significa que estas "devam ser ordenadas, bem regidas, sem se deixar deteriorar ou degradar em suas vias, construções, permitindo que a vida nas cidades seja a menos sofrida possível" (OLIVEIRA, 2005, p. 25). Medauar entende que se entende por cidades sustentáveis "aquelas em que o desenvolvimento urbano ocorre com ordenação, sem caos e destruição, sem degradação, possibilitando uma vida digna para todos" (MEDAUAR, 2004, p. 27).
} 
cidade. Em outra via, entende-se que o direito ao meio ambiente ecologicamente equilibrado encontra na cidade um dos locais cuja garantia deve ser privilegiada, tendo em vista o rápido processo de urbanização, que envolve grande parcela da população e que é capaz de produzir efeitos perversos, especialmente para a população de baixa renda.

\section{CONCLUSÃO}

No Brasil, verifica-se que as discussões sobre reforma urbana, que culminaram com a consagração dos direitos na cidade, como denomina Marcuse, foram influenciadas pelo direito à cidade de Lefebvre, entendido como um valor social-político e filosófico. As normas da Constituição Federal, embora cercadas de disputas na proteção e aplicação, são comemoradas e consideradas como conquistas por aqueles que militam por reforma urbana. A própria consagração do direito a cidades sustentáveis está diretamente relacionada à demanda dos movimentos sociais urbanos. Embora de origens diferentes e com formulações inicialmente diversas, considerando a indivisibilidade dos direitos humanos, entende-se que são aspectos de um mesmo direito, que vai desde demandas específicas sobre aspectos concretos, como moradia, mobilidade, trabalho, ao poder de definir, viver e determinar a execução de projetos de cidade.

O direito fundamental à cidade e os direitos a ele associados são indivisíveis e sua proteção torna-se cada vez mais central e necessária, dado o fenômeno de urbanização em curso. Tais direitos são inter-relacionados e devem ser garantidos progressiva e integralmente. Não é possível falar em garantia ao direito à cidade, sem assegurar mobilidade, moradia, infraestrutura urbana, serviços públicos, meio ambiente sadio, participação democrática, dentre outros; são as pautas específicas que determinam o próprio conteúdo do direito à cidade e o atendimento conjunto entre eles irá garantir cidades justas, inclusivas, resilientes, democráticas.

O direito à cidade, contudo, não é apenas a soma destes direitos e a inter-relação entre eles; ele se relaciona ao poder de influência e criatividade que as pessoas têm de determinar aspectos fundamentais sobre a cidade em que vivem. O mencionado poder de definir os destinos da cidade, a partir de projetos utópicos e desejos na cidade, bem como da prática social exercida no espaço urbano, integram o conteúdo jurídico do direito, produzindo reflexos neste campo, especialmente na gestão democrática das cidades e na imposição de limites à atuação estatal na gestão de espaços públicos. 
Com este conteúdo, o direito à cidade possui previsão na Constituição Federal, especificamente com fundamento nos artigos 3 , $6 ㅇ, 182$ e 225, que consagram os elementos e direitos difusos e sociais a ele diretamente relacionados. Neste sentido, embora o ordenamento jurídico brasileiro tenha utilizado o termo 'direito à cidade' pela primeira vez em 2001, com o Estatuto da Cidade, o mesmo tem proteção em sede constitucional.

No entanto, considerando-se esta centralidade do direito à cidade, tal como aqui proposto, há um déficit relacionado à sua garantia e concretização, o que pode derivar, inclusive, de seu poder de transformação. Aos interessados na continuidade das recorrentes práticas que aprofundam desigualdades sociais, por meio da disponibilização diferenciada de espaços públicos e outros equipamentos e serviços de acordo com o local em questão, financiados com dinheiro público, interessa ter um conceito de direito à cidade vago o suficiente e com pouquíssima aplicação judicial. Assim as coisas ficam como antes.

A interpretação de Lefebvre para o direito à cidade alcança o poder de alteração e decisão, de modo amplo, os destinos e projetos para o espaço urbano. Um direito coletivo, portanto. A partir desta perspectiva de Lefebvre, a gramática do direito à cidade pode assumir um duplo sentido. De um lado, de apresentar um novo projeto para cidade, que a afaste das desigualdades sociais e as mazelas socioambientais. O direito à cidade como questionador de projetos de cidade que privilegiam o falso consenso em torno de ideias abstratas de cidade. De outro, este direito é reivindicação, demanda por direitos a serem exercidos no espaço urbano; um pleito por direitos sociais e difusos diretamente relacionados à dignidade da pessoa humana e outros fundamentos, objetivos e princípios da República brasileira. Conjugando-se os aspectos sociais, políticos e jurídicos, pode-se concluir que se trata de um direito revolucionário, capaz de alterar a vida de milhões de pessoas que vivem na cidade, diminuindo as desigualdades sociais.

\section{REFERÊNCIAS BIBLIOGRÁFICAS}

ACSELRAD, Henri. De "bota-foras" e "zonas de sacrifício" - um panorama dos conflitos ambientais no Estado do Rio de Janeiro. In ACSELRAD, Henri (Org.). Conflito social e meio ambiente no Estado do Rio de Janeiro. Rio de Janeiro: Relume Dumará: Fase, 2004.

0 que é Justiça Ambiental? Rio de Janeiro: Garamond, 2009b.

Sentidos da sustentabilidade urbana. In ACSELRAD, Henri (org.). A duração das cidades. Sustentabilidade e risco nas políticas urbanas. 2a ed. Rio de Janeiro: Lamparina, 2009a, p. 4370. 
A constitucionalização do meio ambiente e a ambientalização truncada do Estado Brasileiro. In OLIVEN, Ruben George Oliven et al (orgs.). A constituição de 1988 na vida brasileira. São Paulo: Aderaldo \& Rothschild, 2008, p. 225-248.

ALFONSIN, Betânia et al. As manifestações de junho de 2013, o processo de construção dos direitos de cidadania no Brasil direito à cidade. In Revista de Direito da Cidade, vol. 07, n. 01, 2015, p. 71-90. Disponivel em: <http://www.epublicacoes.uerj.br/index.php/rdc/article/view/15200>. Acesso em: 18 jan.2017.

ALFONSIN, Betânia. O Estatuto da Cidade e a construção de cidades sustentáveis, justas e democráticas. In Revista Direito e democracia, vol. 2, n. 2. Canoas: Ed. ULBRA, 2001, p. 309318.

BENJAMIN, Antônio Herman. Constitucionalização do ambiente e ecologização da Constituição brasileira. In CANOTILHO, José Joaquim Gomes; MORATO LEITE, José Rubens (Orgs.). Direito constitucional ambiental brasileiro. São Paulo: Saraiva, 2007.

BODIN DE MORAES, Maria Celina. Na medida da pessoa humana. Estudos de direito civilconstitucional. Rio de Janeiro: Renovar, 2010.

BONAVIDES, Paulo. O Estado social e sua evolução rumo à democracia participativa. In SOUZA NETO, Claudio Pereira; SARMENTO, Daniel. Direitos Sociais: fundamentos, judicialização e direitos sociais em espécie. Rio de Janeiro: Lumen Juris, 2008, p. 63-86.

BONDUKI, Nabil. In Constituição 20 anos: Estado, democracia e participação popular. Brasília : Câmara dos Deputados, Edições Câmara, 2009, p. 175-178.

BRASIL, Supremo Tribunal Federal. ADI 1.842-RJ. Relator Min. Luiz Fux. Relator do Acórdão Min. Gilmar Mendes. Brasília, DJ 16/09/2013.

BRENNER, Neil; MARCUSE, Peter; MAYER, Margit. Cities for people, not for profit. An introduction. In BRENNER, Neil; MARCUSE, Peter; MAYER, Margit (coord.). Cities for people, not for profit. Critical urban theory and the right to the city. Londres: Routledge, 2012, p. 1-10.

BUCCI, Maria Paula Dallari. Gestão democrática da cidade. In DALLARI, Adilson Abreu; FERRAZ, Sérgio. Estatuto da Cidade. Comentários à Lei federal 10.257/2001). 2a ed. São Paulo: Malheiros, 2006, p. 334-354.

BULLARD, Robert. Enfrentando o racismo ambiental no século XXI. In ACSELRAD, Henri; HERCULANO, Selene; PÁDUA, José Augusto. Justiça ambiental e cidadania. Rio de Janeiro: Relume Dumará: Fundação Ford, 2004.

CARDOSO, Adauto Lucio. Trajetórias da questão ambiental urbana: da Rio 92 às Agendas 21 locais. Revista Paranaense de Desenvolvimento-RPD, n. 102, 2011, p. 51-69.

CAVALLAZZI, Rosangela Lunardelli. O estatuto epistemológico do Direito Urbanístico brasileiro: possibilidades e obstáculos na tutela do direito à cidade. In COUTINHO, Ronaldo; BONIZZATTO, Luigi (coords). Direito da cidade: novas concepções sobre as relações jurídicas no espaço social urbano. Rio de Janeiro: Lumen Juris, 2007, p. 53-70. 
CAVALLAZZI, Rosangela Lunardelli; AGUIAR, Marlise Sanchotene. Vulnerabilidade e desafios para a tutela do Direito à Cidade: o Projeto Porto maravilha da cidade do Rio de Janeiro. In CAVALLAZZI, Rosangela Lunardelli; AYRES, Madalena J. (Org.). Construções Normativas e Códigos da Cidade na Zona Portuária. Rio de Janeiro: PROURB, 2012, v. 1, p. 129-146.

COUTINHO, Ronaldo. A mitologia da cidade sustentável no capitalismo. In COUTINHO, Ronaldo; BONIZZATTO, Luigi (coords). Direito da cidade: novas concepções sobre as relações jurídicas no espaço social urbano. Rio de Janeiro: Lumen Juris, 2007, p. 17-52.

DI PIETRO, Maria Sylvia Zanella. Função social da propriedade pública. Revista Eletrônica de Direito do Estado, Salvador, Instituto de Direito Público da Bahia, n. 6, abr/maio/jun.2006. Disponível em: <http://www.direitodoestado.com.br/artigo/maria-sylvia-zanella-dipietro/funcao-social-da-propriedade-publica>. Acesso em: 18 jan.2017.

FERNANDES, Edésio. Constructing the 'Right To the City' in Brazil. In Social Legal Studies, 2007, p. 201-219. Disponível em: <http://sls.sagepub.com/cgi/content/abstract/16/2/201>. Acesso em: 27 jan.2017.

Estatuto da Cidade: promovendo o encontro das agendas "verde" e "marrom". In FERREIRA, Heline Silvini; LEITE, José Rubens Morato (orgs.). Estado de direito ambiental: tendências: aspectos constitucionais e diagnósticos. Rio de Janeiro: Forense Universitária, 2004, p. 293-330.

Política urbana na Constituição Federal de 1988 e além: implementando a agenda da Reforma Urbana no Brasil. In Revista OAB-RJ, n. 01, v. 24 (2010), p. 123-142. Disponível em: <http://issuu.com/revistaoabrj/docs/revista_oabrj_25>. Acesso em: 25 ago.2015.

A nova ordem jurídico-urbanística no Brasil. In ALFONSIN, Betânia; FERNANDES, Edésio (orgs.). Direito urbanístico: estudos brasileiros e internacionais. Belo Horizonte: Del Rey, 2006, p. 3-23.

FIORILLO, Celso A. Direito a cidades sustentáveis no âmbito da tutela constitucional do meio ambiente artificial. In FERREIRA, Heline Silvini; LEITE, José Rubens Morato (orgs.). Estado de direito ambiental: tendências: aspectos constitucionais e diagnósticos. Rio de Janeiro: Forense Universitária, 2004, p. 271-292.

HARVEY, David. Cidades rebeldes: do direito à cidade à revolução urbana. São Paulo: Martins Fontes, 2014.

KLOEPFER, Michael. A caminho do Estado Ambiental? A transformação do sistema político e econômico da República Federal da Alemanha através da proteção ambiental especialmente desde a perspectiva da ciência jurídica. In SARLET, Ingo Wolfgang (Org.). Estado Socioambiental e Direitos Fundamentais. Porto Alegre: Livraria do Advogado, 2010.

Lefebvre, Henri. A revolução urbana. Belo Horizonte: Ed. UFMG, 1999.

O direito à cidade. São Paulo: Centauro, 2001.

LIRA, Ricardo Pereira. Elementos de Direito Urbanístico. Rio de Janeiro: Renovar, 1997.

MARCUSE, Peter. O direito nas cidades e o direito à cidade? In SUGRANYES, Ana; MATHIVET, Charlotte (coords.). Ciudades para tod@s. Por el derecho a la ciudad, propuestas y experiências. 
Santiago de Chile: Habitat International Coalition, 2010, p. 89-102. Disponível em: <http://www.hic-al.org/documento.cfm?id_documento=1402>. Acesso em: 18 jan.2017.

MEDAUAR, Odete; ALMEIDA, Fernando Dias Menezes de. Estatuto da Cidade. Lei 10.257, de 10.07.2001, comentários. 2ạ ed. rev., atual. e ampl. São Paulo: Revista dos Tribunais, 2004.

MOLINARO, Carlos Alberto. Direito à cidade e proibição de retrocesso. In Anais do 13은 Congresso Internacional de Direito Ambiental. Direito ambiental, mudanças climáticas e desastres : impactos nas cidades e no patrimônio cultural. São Paulo: Imprensa Oficial do Estado de São Paulo, 2009, p. 21-36.

MOTTA, Maurício Jorge Pereira da et al. Direito ambiental das cidades: novas perspectivas acerca da sustentabilidade das regiões urbanas. In Revista de Direito da Cidade, v. 2, 2006, p.6079.

MOVIMENTO PASSE LIVRE. Não começou em Salvador, não vai terminar em São Paulo. In MARICATO, Ermínia et al. Cidades rebeldes: Passe Livre e as manifestações que tomaram as ruas no Brasil. São Paulo: Boitempo: Carta Maior, 2013, p. 13-19.

OLIVEIRA, Regis Fernandes de. Comentários ao Estatuto da Cidade. 2a ed. rev., atual. e ampl. São Paulo: Revista dos Tribunais, 2005.

OST, François. A natureza à margem da Lei: a ecologia à prova do Direito. Lisboa: Instituo Piaget, 1995.

PIOVESAN, Flávia. O direito ao meio ambiente e a Constituição de 1988. In BENJAMIN, Antonio Herman; FIGUEIREDO, Guilherme José Purvin de. Direito ambiental e as funções essenciais à justiça: o papel da advocacia de Estado e da Defensoria Pública na proteção do meio ambiente. São Paulo: Revista dos Tribunais, 2011.

Direitos sociais, econômicos e culturais e direitos civis e políticos. In SUR. Revista Internacional de Direitos Humanos. Ano 1, Número 1. São Paulo, 2004, p. 21-48.

PORTILHO, Liana. Nova ordem jurídico-urbanística: função social da propriedade na prática dos tribunais. Rio de Janeiro: Lumen Juris, 2006.

QUEIROZ, Cristina. Direitos fundamentais sociais. Funções, ámbito, conteúdo, questões interpretativas e problemas de justiciabilidade. Coimbra: Coimbra Editora, 2006.

RIBEIRO, Luiz Cesar de Queiroz; SANTOS JUNIOR, Orlando Alves. Desafios da Questão Urbana na Perspectiva do Direito à Cidade. In SANTOS JUNIOR, Orlando Alves et al (org.). Políticas públicas e direito à cidade: programa interdisciplinar de formação de agentes sociais e conselheiros municipais. Rio de Janeiro: Letra Capital: Observatório das Metrópoles: IPPUR/UFRJ, 2011, p. 11-16.

SANTILLI, Juliana. Os "novos" direitos socioambientais. Revista Direito e Justiça: Reflexões Sociojurídicas. Ano VI, no 9. Porto Alegre: Ed. PUC-RS, novembro 2006.

SANTOS JUNIOR, Orlando Alves dos. A Produção Capitalista do Espaço, os Conflitos Urbanos e o Direito à Cidade. In SANTOS JUNIOR, Orlando Alves et al (orgs.). Políticas públicas e direito à 
cidade: programa interdisciplinar de formação de agentes sociais e conselheiros municipais. Rio de Janeiro: Letra Capital: Observatório das Metrópoles: IPPUR/UFRJ, 2011, p. 67-74.

Urban common space, heterotopia and the right to the city: reflections on the ideas of Henri Lefebvre and David Harvey. Urbe. Revista Brasileira de Gestão Urbana, v. 6, n. 2, p. 146157, 2014.

SANTOS JUNIOR, Orlando Alves dos; MONTANDON, Daniel Todtmann. Síntese, desafios e recomendações. In SANTOS JUNIOR, Orlando Alves dos; MONTANDON, Daniel Todtmann (orgs.). Os planos diretores municipais pós-estatuto da cidade: balanço crítico e perspectivas. Rio de Janeiro: Letra Capital: Observatório das Cidades: IPPUR/UFRJ, 2011, p. 27-56.

SARLET, Ingo W.; FENSTERSEIFER, Tiago. Direito constitucional ambiental: constituição, direitos fundamentais e proteção do ambiente. 2ª ed. São Paulo: Revista dos Tribunais, 2012.

SARMENTO, Daniel. A proteção judicial dos direitos sociais: alguns parâmetros ético-jurídicos. In SOUZA NETO, Claudio Pereira; SARMENTO, Daniel. Direitos Sociais: fundamentos, judicialização e direitos sociais em espécie. Rio de Janeiro: Lumen Juris, 2008a, p. 553-586.

Supremacia do interesse público? As colisões entre direitos fundamentais e interesses da coletividade. In ARAGÃO, Alexandre Santos de; MARQUES NETO, Floriano de Azevedo (coords.). O Direito administrativo e seus novos paradigmas. Belo Horizonte: Fórum, 2008b, p. 97-144.

SAULE JUNIOR, Nelson. O Direito à Cidade como paradigma da governança urbana democrática. Instituto Pólis. Publicado em: 30 mar. 2005. Disponível em: <http://www.polis.org.br/uploads/750/750.pdf>. Acesso em: 27 jan. 2017.

SAULE JUNIOR, Nelson; UZZO, Karina. La trayectoria de la reforma urbana en Brasil. In SUGRANYES, Ana; MATHIVET, Charlotte (coords.). Ciudades para tod@s. Por el derecho a la ciudad, propuestas y experiências. Santiago de Chile: Habitat International Coalition, 2010, p. 259-270. Disponível em: <http://www.hic-al.org/documento.cfm?id_documento=1402>. Acesso em: 18 jan.2017.

SILVA, José Afonso da. Direito ambiental constitucional. 10a ed. atual. São Paulo: Malheiros, 2013.

SILVA, Virgílio Afonso da. Direitos fundamentais. Conteúdo essencial, restrições e eficácia. São Paulo: Malheiros, 2009.

SOUZA FILHO, Carlos Frederico Marés de. O direito de ser povo. In SARMENTO, Daniel; IKAWA, Daniela; PIOVESAN, Flávia (Coord.). Igualdade, diferença e direitos humanos. Rio de Janeiro: Lumen Juris, 2010.

SOUZA, Marcelo Lopes de. Ciudades brasileñas, junio de 2013: lo(s) sentido(s) de la revuelta. In Revista Contrapunto: Territorios urbanos en disputa, n.3. Montevideo: Centro de Formación Popular del Oeste de Montevideo; Comisión Sectorial de Extensión y Actividades en el Medio da Universidad de la República, 2013, p. 105-127.

SUNDFELD, Carlos Ari. O Estatuto da Cidade e suas diretrizes gerais. In DALLARI, Adilson Abreu; FERRAZ, Sérgio. Estatuto da Cidade. Comentários à Lei federal 10.257/2001). 2a ed. São Paulo: Malheiros, 2006, p. 45-60. 
TEPEDINO Gustavo; SCHREIBER Anderson. A Garantia da Propriedade no Direito Brasileiro. Revista da Faculdade de Direito de Campos, Ano VI, n. 6 - junho de 2005, p. 101-119.

TRINDADE, Thiago Aparecido. Direitos e cidadania: reflexões sobre o direito à cidade. Lua Nova, São Paulo, 87, 2012, p. 139-165.

VAINER, Carlos. Quando a cidade vai às ruas. In MARICATO, Ermínia et al. Cidades rebeldes: Passe Livre e as manifestações que tomaram as ruas no Brasil. São Paulo: Boitempo: Carta Maior, 2013, p. 35-40.

WERNECK, Augusto. Função social da cidade. Plano Diretor e favelas. A regulação setorial nas comunidades populares e a gestão democrática das cidades. In COUTINHO, Ronaldo; BONIZZATTO, Luigi (coords). Direito da cidade: novas concepções sobre as relações jurídicas no espaço social urbano. Rio de Janeiro: Lumen Juris, 2007, p.123-142.

Trabalho enviado em 30 de janeiro de 2017.

Aceito em 12 de abril de 2017. 